DIVERSITY, ABUNDANCE AND FATE OF ICE ALGAE AND PHYTOPLANKTON

IN THE BERING SEA

By

Anna Szymanski

RECOMMENDED:

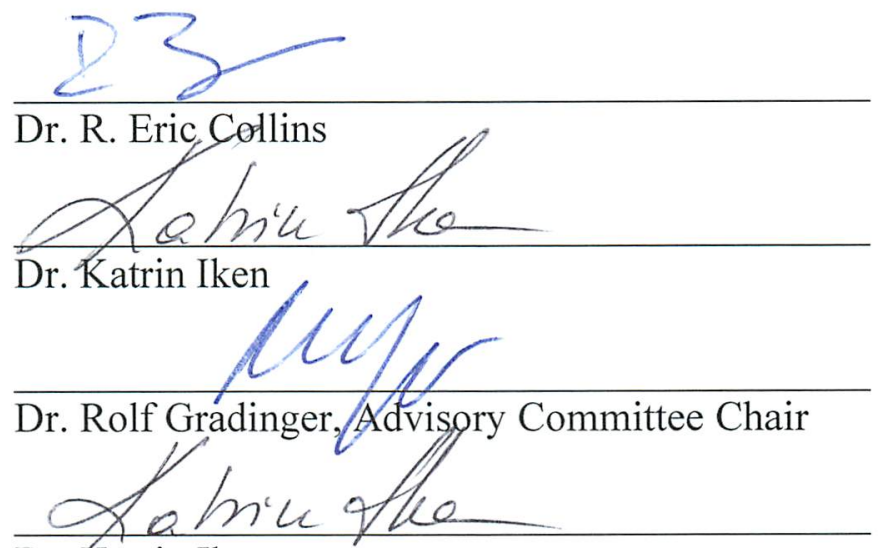

Dr. Katrin Iken

Program Head, Marine Science and Limnology

APPROVED:

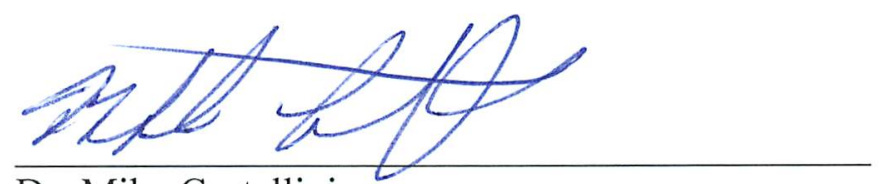

Dr. Mike Castellini

Dean, School of Fisheries and Ocean Sciences

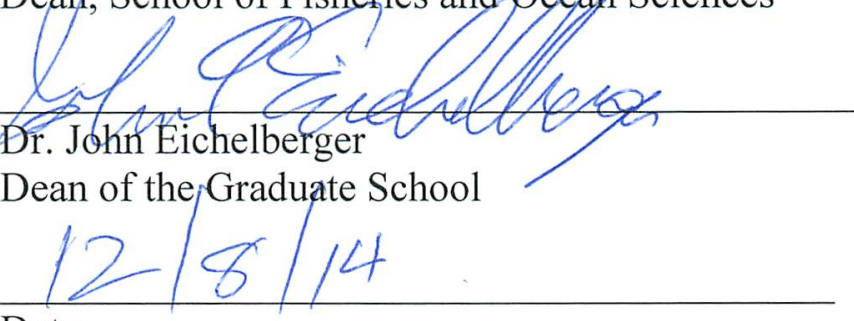

Date 



\title{
DIVERSITY, ABUNDANCE AND FATE OF ICE ALGAE AND PHYTOPLANKTON IN THE BERING SEA
}

\author{
A \\ THESIS \\ Presented to the Faculty \\ of the University of Alaska Fairbanks \\ in Partial Fulfillment of the Requirements \\ for the Degree of
}

MASTER OF SCIENCE

By

Anna Szymanski, B.A.

Fairbanks, Alaska

December 2014 


\begin{abstract}
Sea ice algae are an essential part of Arctic and subarctic ecosystems. They significantly contribute to total algal primary production, serve as an early spring food source for both pelagic and benthic biota, and can seed the spring phytoplankton bloom during periods of ice melt. In the subarctic Bering Sea, virtually nothing has been known about the composition of the ice algal community, its magnitude, and its connection to pelagic and benthic ecosystems. This study, therefore, focused on the diversity, abundance, and ultimate fate of ice algae in the Bering Sea using sea ice, water and sub-ice sediment trap samples collected during two spring periods: ice growth (March to mid-April) and ice melt (mid-April to May) in 2008 and 2009. Ice algal species composition was comparable to those in Arctic regions. The phytoplankton species inventory was similar to that found in the overlying ice, suggesting that the spring phytoplankton were seeded from the ice algae. Algal abundance in the ice was on average three orders of magnitude higher than in the water column throughout both periods, as the extensive Bering Sea ice cover in 2008-2009 delayed the phytoplankton bloom. There was a substantial increase in the vertical flux of algal cells beneath the ice during the period of ice melt, but measurable amounts appeared as early as mid-March. The majority of this flux was composed of healthy algal cells, making it a rich food source for benthic organisms. Differences in the relative species composition between ice and trap samples indicate that algal fate was influenced by the species specific sinking rate of algal cells, among other factors, in the water column. In conclusion, ice algae in the Bering Sea are diverse and abundant, and contribute to both pelagic and benthic systems.
\end{abstract}





\section{Table of Contents}

Page

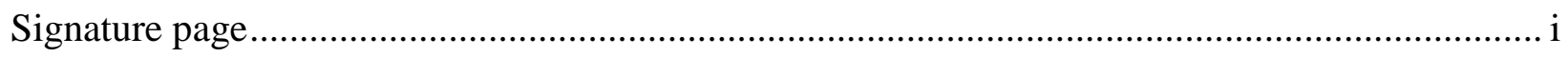

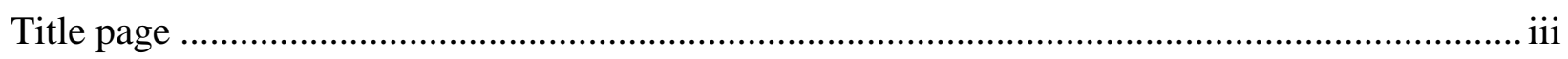

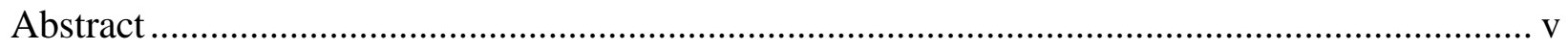

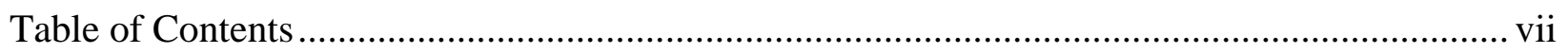

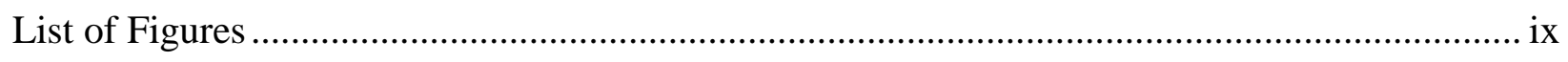

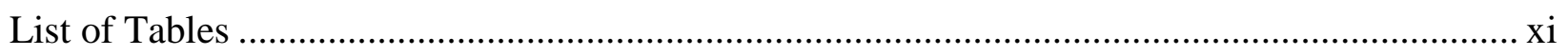

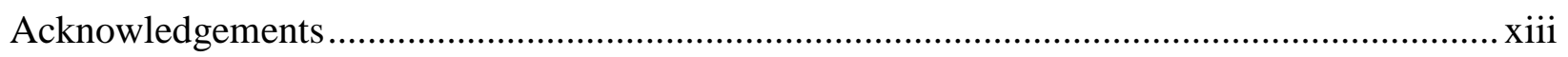

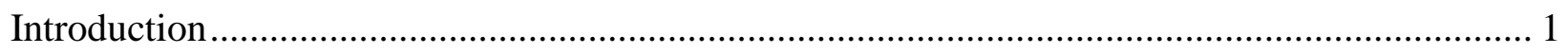

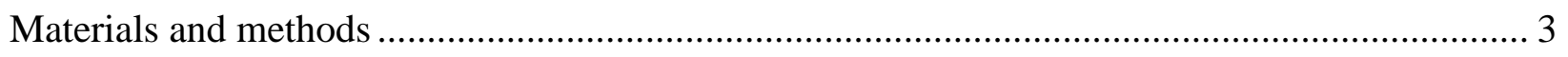

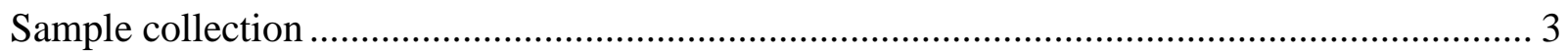

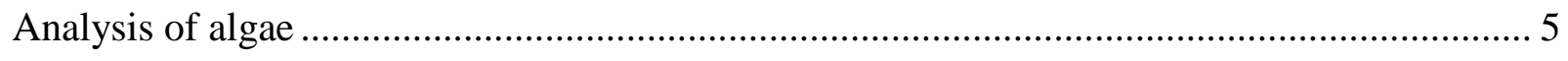

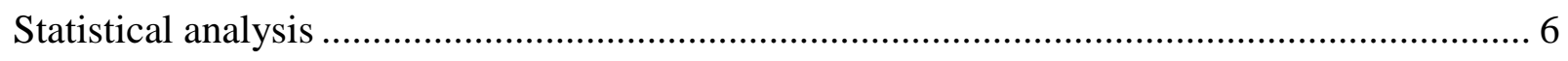

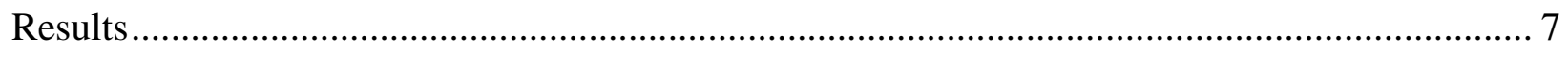

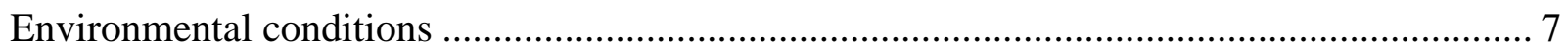

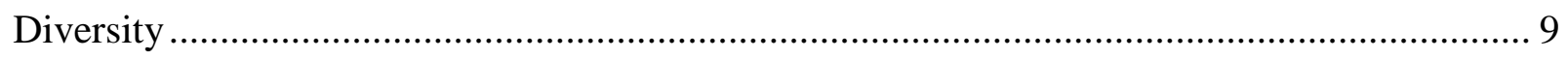

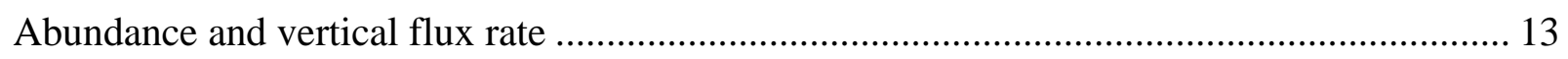

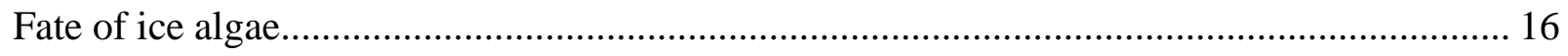

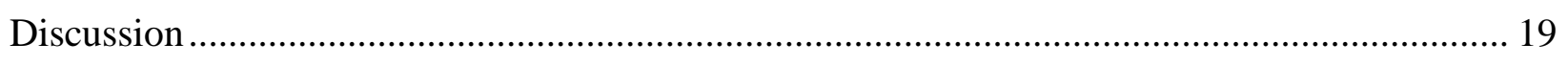

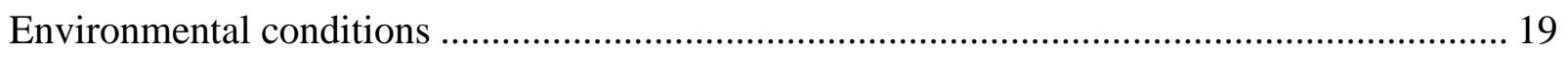

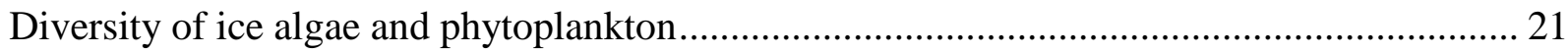

Abundance of ice algae and phytoplankton …………….................................................... 26

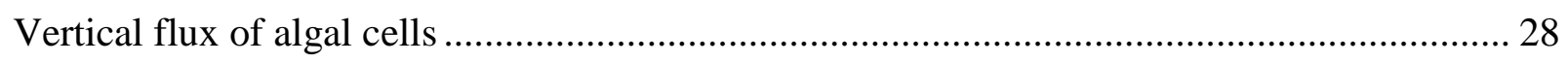

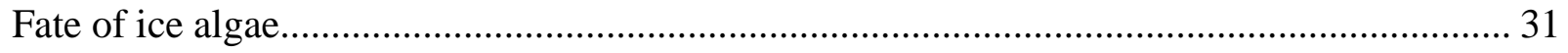

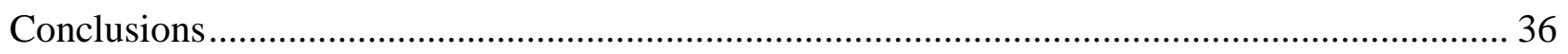

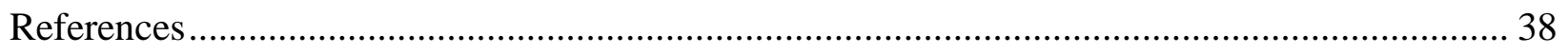




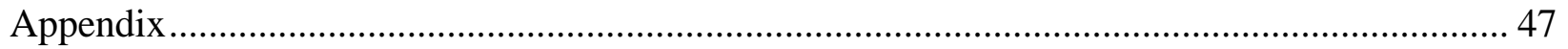




\section{List of Figures}

Page

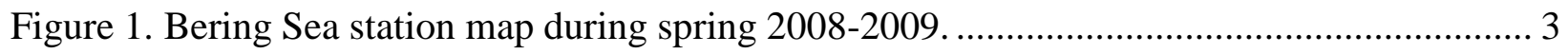

Figure 2. Environmental conditions at stations sampled during ice growth and ice melt periods. 8

Figure 3. Multidimensional scaling plot based on the environmental conditions...................... 9

Figure 4. Rarefaction curves showing extrapolated species richness. ................................... 13

Figure 5. Multi-dimensional scaling plots of the relative species abundance. ........................ 17

Figure 6. Relative abundance (\% of total) of species in ice, water and sediment trap samples ... 18

Figure 7. Comparison of the euphotic zone (as indicated by the 1\% PAR depth) and the mixed

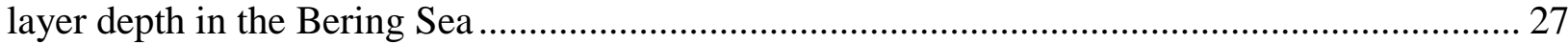





\section{List of Tables}

Page

Table 1. Diatom species inventory for Bering Sea ice, water and sediment trap samples ........... 10

Table 2. Mean algal characteristics during ice growth and ice melt periods ................................ 14

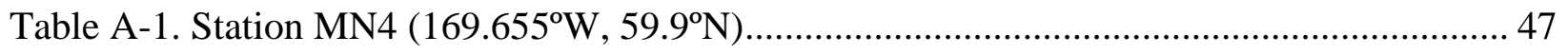

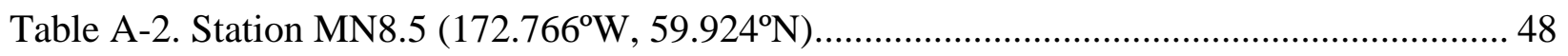

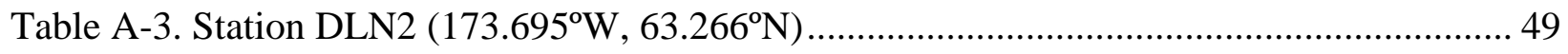

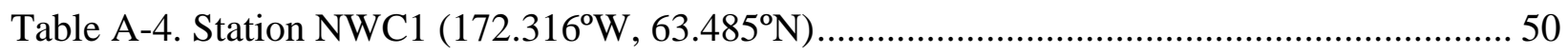

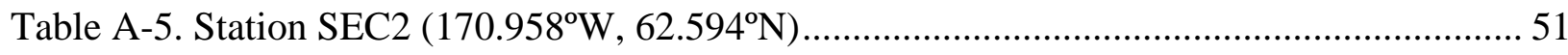

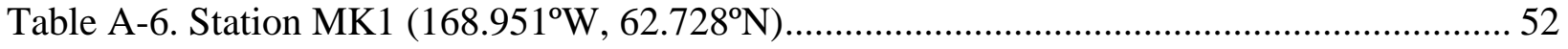

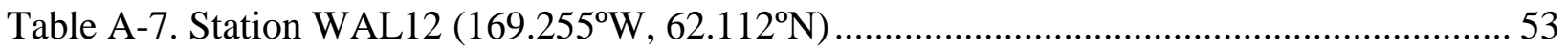

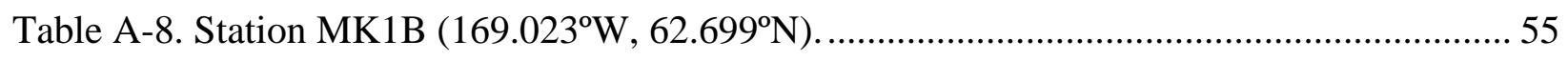

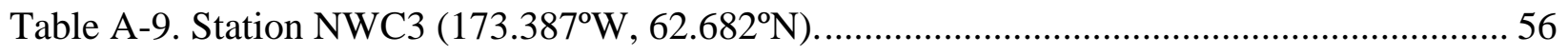

Table A-10. Station MN4.5 (169.938º

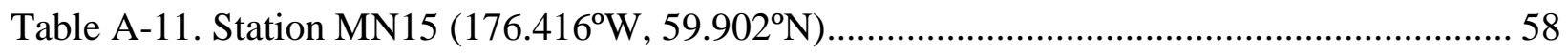

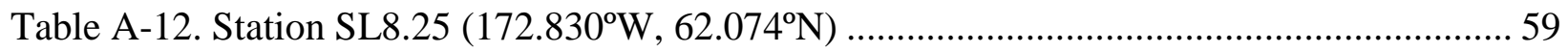

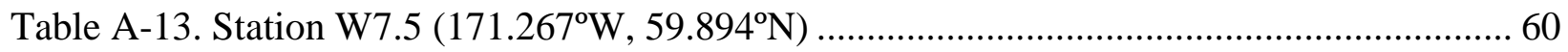

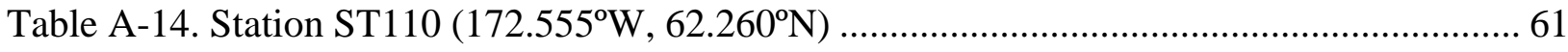

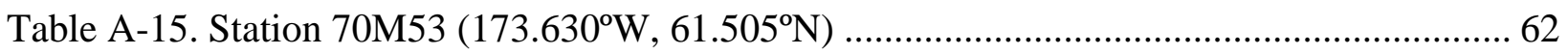

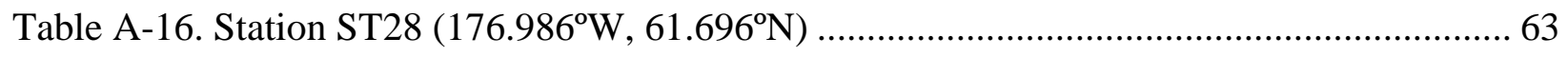

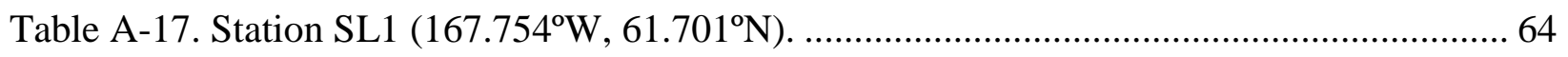

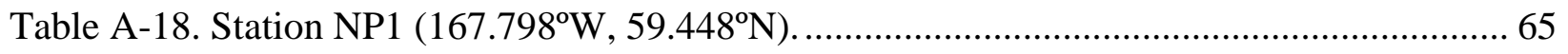

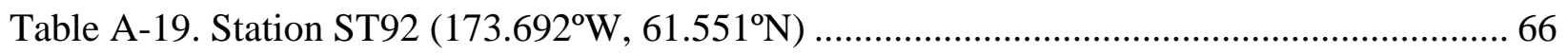

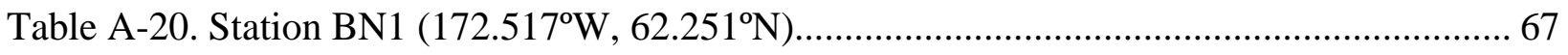





\section{Acknowledgements}

I would like to express my sincere thanks to my graduate adviser, Rolf Gradinger, for his unfailing patience, guidance and support throughout this project, and for serving as an example of all that can be accomplished both in science and in life. I thank my graduate committee members, Katrin Iken and Eric Collins, for helping to bring perspective, perspicacity and proper punctuation to this project. Thanks to all of the many scientists and crew members involved in the BEST cruises without whom this project would not have been possible. I want to thank Ken Severin from the Advanced Instrumentation Laboratory at the University of Alaska Fairbanks for his enthusiasm and assistance using the scanning electron microscope. Thanks to Arny Blanchard for the hours spent discussing statistical analysis with me. I very much appreciate the

help of Cecilie von Quillfeldt from the Norwegian Polar Institute, who shared her knowledge and skills on ice algal taxonomy, and who provided me with excellent resources on diatom identification. I also want to thank all of the participants in the 2013 Polar Marine Diatom Taxonomy Workshop, who offered their insight and opinions on diatom morphology, and who reviewed many of the species identifications in this project. Thanks to Mike Lomas from the Bigelow Laboratory for Ocean Sciences for graciously providing me with data on the Bering Sea water column structure. Financial support for this research was provided by the National Science Foundation, the Center for Global Change, the Howard Feder and David Shaw Graduate Scholarship, and the Robert and Kathleen Byrd Scholarship, all of which were invaluable for the completion of this project. 



\section{Introduction}

Seasonal sea ice is among the most defining features of the subarctic Bering Sea shelf, influencing both the physical and biological structure of the water column not only during periods of ice cover but throughout the year (Hunt et al. 2008; Stabeno et al. 2010; Stabeno et al. 2012a). Ice extent and the timing of ice melt dictate the development of primary production in the water column, and the ice itself supports a rich growth of ice algae long before the first spring phytoplankton bloom. Despite the generally acknowledged importance of ice algae as a food source for sympagic, pelagic and benthic organisms in the Arctic (Bluhm and Gradinger 2008), virtually nothing is known about the diversity of the Bering Sea ice algal community, its connection with the underlying phytoplankton, and its ultimate fate during the annual ice melt in the spring.

Sea ice can cover the entire Bering Sea shelf during winter and spring, extending over an average of $200,000 \mathrm{~km}^{2}$ before completely retreating each summer (Wendler et al. 2013). The ice impacts the climate, oceanography and productivity of the Bering Sea, mediating the exchange of heat and gases between the atmosphere and the water, influencing light availability, water temperature and salinity, and providing a physical habitat that is essential for many marine mammals. The ice also supports a large community of microorganisms within it, which has been virtually unstudied. In the Bering Sea, Alexander and Chapman (1981) found high chlorophyll concentrations within the ice, indicating a substantial standing stock of ice algae, but little additional knowledge on the structure and importance of this community has been gathered in the past three decades.

The contribution of ice algae to the overall primary production in the Bering Sea is thought to be up to $10 \%$ of the annual total (McRoy and Goering 1974; R. Gradinger unpublished data). While this fraction is less than stated for other Arctic regions, where the proportion can be over half (e.g., Gosselin and Levasseur 1997), the timing of the ice algal bloom makes it an essential part of the Bering Sea ecosystem. Across the Arctic, ice algal blooms can precede phytoplankton blooms by as much as three months (Leu et al. 2011). This makes ice algae a crucial first food source for zooplankton during the early spring (Tourangeau 
and Runge 1991; Michel and Legendre 1996; Durbin and Casas 2014). Ice algae can also contribute a significant proportion to the total carbon export to the benthos, providing a high quality food source for benthic organisms (e.g., Boetius et al. 2013). In some seasonally icecovered seas, ice algae can remain viable in the water column after ice melt, seeding the spring phytoplankton blooms and further extending their importance in the ecosystem (e.g., Michel et al. 1993; Haecky et al. 1998). Ecosystem modeling studies have highlighted the relevance of seeding for the development of the spring phytoplankton bloom in the Bering Sea (Jin et al. 2007), but direct evidence based on field observations has been lacking. While a unique, shortlived phytoplankton community occurs in association with the receding ice edge, the origin (ice versus plankton) has remained unknown due to the lack of information on the algal community composition within the ice (Schandelmeier and Alexander 1981). Similarly, the partitioning of the often high vertical flux of organic matter beneath the ice in the Bering Sea between phytoplankton and released ice algae has not been determined (Cooper et al. 2013).

Based on the above outlined substantial gaps in our understanding of early spring sea ice algal and phytoplankton bloom characteristics in the Bering Sea, I defined three major objectives for this study: first, to characterize the diversity and abundance of the Bering Sea ice algal community during periods of ice growth and ice melt; second, to determine the influence of ice algae on the phytoplankton community during these periods; and third, assess the possible fates of ice algae during ice melt through the examination of ice, water and sub-ice sediment trap samples. I predicted that the ice algal abundance would exceed that of the phytoplankton until the start of the ice-edge bloom, which I expected to coincide with a significant increase in vertical flux rates; I further hypothesized that ice algae would contribute to seeding the ice-edge phytoplankton bloom during the spring. 


\section{Materials and methods}

\section{Sample collection}

The Bering Sea is dominated by a broad shallow shelf that extends over $1000 \mathrm{~km}$ south of the Bering Strait with an average depth of only $65 \mathrm{~m}$ (Wang et al. 2007). Ice algae and phytoplankton were collected from across the shelf as part of the Bering Sea Ecosystem Study during three spring cruises on the USCGC Healy: HLY0802 April 4-30, 2008; HLY0901 March 17-27, 2009; and HLY0902 April 7-May 2, 2009. Sampling occurred under a range of ice conditions. I defined two ice periods based on observed changes in the temperature gradient between the surface and bottom of the sea ice (R. Gradinger, unpublished data): the ice growth period was defined as prior to day 100 of the year, while the ice melt period was defined as extending from day 100 of the year until the end of sampling. This approach eliminated effects of regional and inter-annual differences in the physical growth regime of the sea ice algae. Ten stations were sampled during each period for a total of 20 stations, extending across the central Bering Sea shelf south of St. Lawrence Island (Fig. 1; 58.21-63.48 $\mathrm{N} ; 167.75-178.90^{\circ} \mathrm{W}$ ).

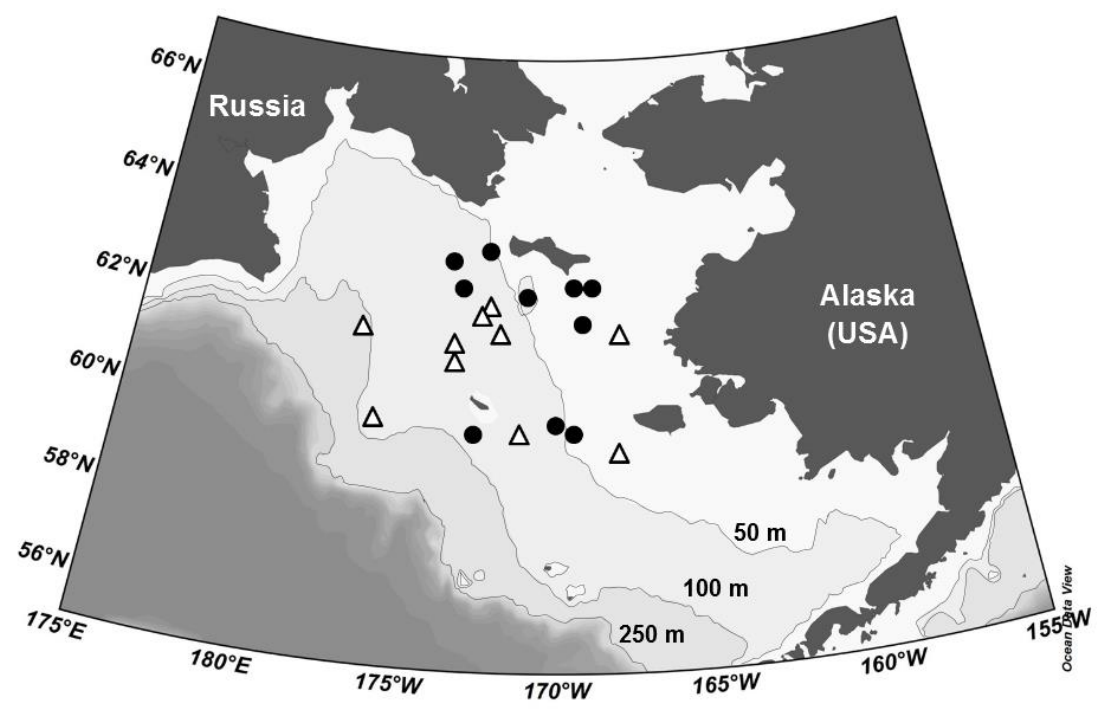

Figure 1. Bering Sea station map during spring 2008-2009. Black circles indicate stations sampled during the period of ice growth (before day 100 of the year), open triangles indicate stations sampled during the period of ice melt (day 100 and later of the year). 
From each station, a set of three algal samples was collected from the ice, water and subice sediment traps. Ice cores were obtained using a Kovacs ice corer (diameter $9 \mathrm{~cm}$ ). The bottom $2 \mathrm{~cm}$ of the ice core were used for the analysis of the algal community; this segment was melted slowly in filtered sea water to prevent osmotic stress to the ice algae (Garrison and Buck 1986). Phytoplankton was collected at $5 \mathrm{~m}$ water depth through a core hole in the ice using a Kemmerer water sampler. To determine the vertical flux rate of algal cells, cylindrical sediment traps (KC Denmark; diameter $10 \mathrm{~cm}, 1: 10$ aspect ratio) filled with filtered seawater were deployed beneath the ice at a depth of $5 \mathrm{~m}$ for 4-6 hours. Algal samples were fixed in a 1\% final concentration of buffered formaldehyde-sea water solution. Samples from HLY0902 were lost; however, a second set of ice and sediment trap samples were taken on this cruise for a separate study. These samples were collected as described above; however, melted ice and sediment trap samples were then concentrated over a $20 \mu \mathrm{m}$ filter prior to fixing. Large cells $(>20 \mu \mathrm{m})$ contributed over $94 \%$ to the algal abundance in the ice and traps in the unfiltered samples from 2008, and there were no significant differences when I compared ice algal abundance (cells $1^{-1}$ ) and vertical flux rate (cells $\mathrm{m}^{-2} \mathrm{day}^{-1}$; t-tests, $\mathrm{p}>0.05$ for both comparisons), and the relative species composition in ice and trap samples (PERMAOVA, $\mathrm{p}>0.05$ for both comparisons) between the filtered samples from 2009 and non-filtered samples from the same time period in 2008. Therefore, I included these samples in the analysis; however, there were no water samples available from HLY0902.

A set of environmental variables were recorded at each station. A CTD (SEACAT 19plus) was lowered by hand through auger holes in the ice to measure under-ice hydrography. Temperature, salinity and light intensity in the PAR range $(400-700 \mathrm{~nm})$ were recorded in $1 \mathrm{~m}$ increments from the surface to approximately $20 \mathrm{~m}$ depth. For comparison among stations and relation to ice data, I used the light data at $2 \mathrm{~m}$ depth to minimize errors due to the corer hole (Petrich et al. 2012). For inorganic nutrient analysis (i.e., nitrate, phosphate, silicate) water samples were collected from the ship using Niskin bottles every $10 \mathrm{~m}$ starting at the surface. Ice thickness was recorded from the length of ice cores, and snow depth was averaged from 10 random measurements at each station. Approximate percent ice cover and primary ice type (e.g., 
first year ice, young grey-white ice, young grey ice, pancake ice, new ice, brash ice; Eicken et al. 2009) were recorded by shipboard observers; primary ice type was assigned a numerical value according to Eicken et al. (2009). Day length at each station was calculated using the U.S. Naval Observatory website (http://aa.usno.navy.mil/data/docs/rs_OneDay.php). Environmental data used in this study are available online at http://beringsea.eol.ucar.edu/.

\section{Analysis of algae}

I processed all algal samples at the University of Alaska Fairbanks in 2013-2014. After bringing algal cells into homogenous suspension by hand, I concentrated 5-50 mL of each sample using the Utermöhl settling method (Edler and Elbrächter 2010), depending on cell density. I analyzed samples under an inverted microscope (Zeiss Axiovert 35) with phase contrast within $48 \mathrm{~h}$ of the start of settling. Abundance data were based on the enumeration of representative sub-samples, according to the sampling procedures outlined in the UNESCO phytoplankton manual (Edler and Elbrächter 2010), with a minimum of 500 cells counted per sample. Empty cells were recorded, but not included in abundance counts. Diatoms were identified to the species level whenever possible, with taxonomy primarily based on Lebour (1930) and Tomas (1997); all names were verified with the most recent entries in the World Register of Marine Species (WoRMS, accessed May 2014). Flagellates were counted but not identified, as they contributed very little to the overall algal abundance in the Bering Sea (on average $<3 \%$ in the ice and the water).

After quantification by light microscopy, I processed a subset of ice algal samples with sufficient remaining biomass for more refined taxonomic analysis. I cleaned ten samples using a 1:1 ratio of $5.25 \%$ sodium hypochlorite and water to clear the organic material from the diatom frustules (Carr et al. 1986), then fixed a portion of each sample to a slide using Naphrax (Phycotech) with a refractive index of 1.73 (Hasle and Fryxell 1970). I then examined each sample under an inverted microscope (Zeiss Telaval 31). The remaining material was filtered onto a $0.8 \mu \mathrm{m}$ Nuclepore filter and allowed to dry overnight, before being sputter-coated with gold and visualized using scanning electron microscopy with an electron microprobe (JEOL JXA-8530F). This non-quantitative species analysis was used to enhance the recorded diversity 
of the ice algal community. Water and sediment trap samples were not reexamined, as there was insufficient biomass remaining in those samples.

\section{Statistical analysis}

Based on observations of vertical temperature gradients in the Bering Sea ice (Gradinger, unpublished data), I defined two time periods a priori: the period of ice growth and the period of ice melt (see above). This division was later confirmed through the analysis of multi-dimensional scaling plots based on various other environmental variables (see results, Fig. 3). Eight environmental variables were compared between the ice growth period and the ice melt period using two-sample t tests: ice thickness, ice concentration, snow depth, light intensity beneath the ice, surface salinity, and surface water concentrations of nitrate, phosphate and silicate. Primary ice type was compared between ice growth and ice melt periods using a one-way ANOVA.

To extrapolate species richness, I used EstimateS software (Colwell 2000) to create rarefaction curves with Chao 1 and Chao 2 bias-corrected formulas. This approach allowed for the prediction of the actual species richness in ice, water and sediment trap samples assuming a maximum of 100 samples in each of the three sample sets. To visualize differences in the species composition between the three sample sets, I created MDS plots based on Bray-Curtis similarity matrices using PRIMER E version 6 software. Because abundances among samples were of different orders of magnitude, I used relative species abundances (as \% of total) to standardize the data across the three sample sets; samples were then divided between ice growth and ice melt periods.

To compare the overall species composition between the three sample sets, I performed a permutational multivariate ANOVA (PERMANOVA, Anderson 2001) using PRIMER. Comparisons were made separately for periods of ice growth and ice melt using relative species abundances. To determine the contribution of individual species to the differences between sample sets during each period, I used the similarity percentages routine (SIMPER) in PRIMER on relative species abundances; this allowed me to compile a list of those species that individually contributed $5 \%$ or more to the dissimilarity between any two sample sets. To compare the abundance of individual species among sample sets during each period, I performed 
an ANOVA on relative species abundances from each period with sample type as the factor. The data were square-root transformed to meet assumptions of homoscedasticity; however, due to the high variability that is characteristic of biological data, one test still failed to meet the assumption (Paralia sulcata, Brown-Forsyth test, $\mathrm{p}<0.05$ ).

I determined correlations among the community composition in the ice, water and traps using a Mantel's test (Mantel 1967) in the R package vegan. Correlations between seven environmental variables (ice concentration, primary ice type, ice thickness, snow depth, light levels beneath the ice, nutrient concentrations in the water, day length) and ice algal abundance, phytoplankton abundance, and vertical flux rates were made using PRIMER's BEST-BIOENV routine with 99 permutations.

I compared algal abundance and vertical flux rate between years and periods using two sample t-tests. Comparisons between years were conducted using only overlapping dates (April 4-28). Phytoplankton abundance was not included in this analysis as water samples were unavailable during April 2009. The relationships between cell counts and chlorophyll $a$ concentrations in the sediment trap samples were determined using linear regressions for samples separately during ice growth and ice melt periods.

\section{Results}

\section{Environmental conditions}

The environmental conditions were distinctly different for the two selected periods of growing versus melting sea ice (Fig. 2). The ice growth period had significantly thicker ice, ranging from 0.50 to $1.00 \mathrm{~m}$ and averaging $0.82 \mathrm{~m}$ compared to 0.35 to $0.90 \mathrm{~m}$, and a mean of $0.55 \mathrm{~m}$ for the melt period ( $\mathrm{t}$-test, $\mathrm{p}<0.05$ ). The primary ice type also was significantly different between periods, with more white first year ice and young grey-white ice during ice growth compared to a wide range of ice types during the ice melt phase (ANOVA, $\mathrm{p}<0.05$ ). The day length during ice growth was significantly shorter (t-test, $\mathrm{p}<0.05)$, ranging from 712 to 833 min with an average of 757 min before day 100 (ice growth) compared to 840 to 994 min with a mean of 903 min after day 100 (ice melt). The ice concentration and snow depth values were 
slightly higher during ice growth, and the light intensities beneath the ice were slightly lower compared to ice melt conditions; however, none of these differences were significant (t-test, $\mathrm{p}>0.05$ for all comparisons). There were no significant differences in surface water nutrient concentrations (nitrate, phosphate and silicate) or surface salinities between the ice growth and ice melt periods (t-test, $\mathrm{p}>0.05$ for all comparisons).
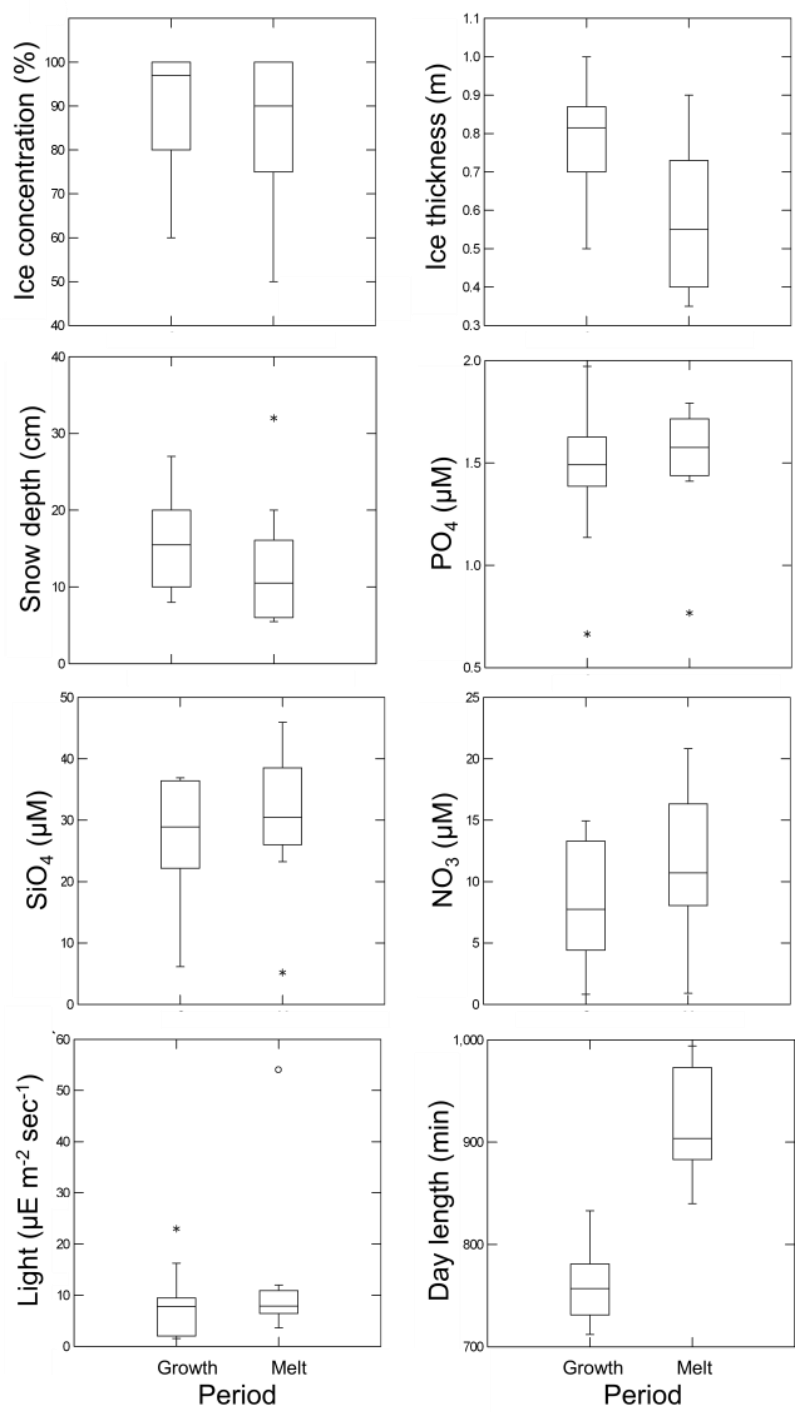

Figure 2. Environmental conditions at stations sampled during ice growth and ice melt periods. Phosphate $\left(\mathrm{PO}_{4}\right)$, silicate $\left(\mathrm{SiO}_{4}\right)$ and nitrate $\left(\mathrm{NO}_{3}\right)$ from the surface water. 
A multidimensional scaling plot of the above environmental variables showed the clear separation in environmental conditions at stations sampled during the period of ice growth and the period of ice melt (Fig. 3).

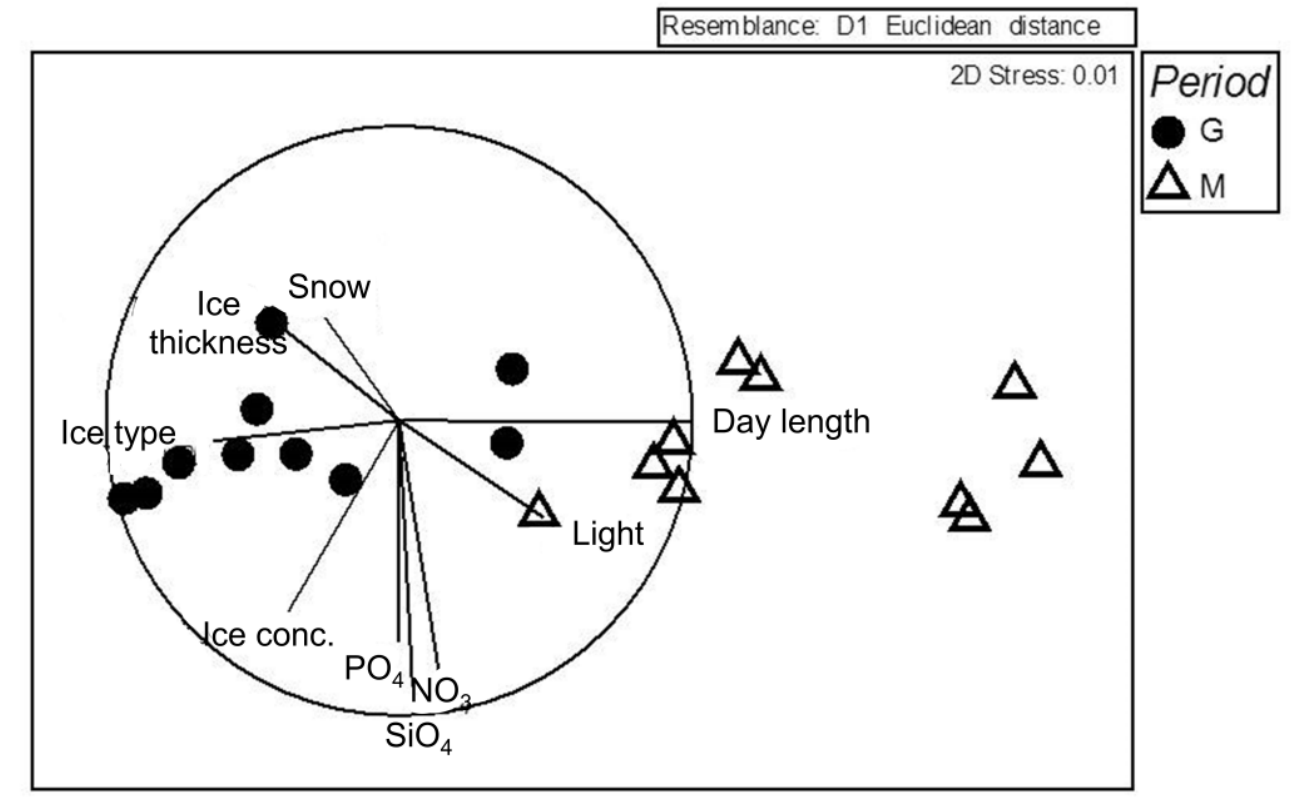

Figure 3. Multidimensional scaling plot based on the environmental conditions at stations sampled during ice growth and ice melt periods. Black circles indicate stations sampled during ice growth $(\mathrm{G})$, open triangles indicate stations sampled during ice melt (M). A stress value of 0.01 indicates an excellent representation in two-dimensional space. Conc. concentration.

\section{Diversity}

Diatoms were the dominating group both in terms of abundances and species richness, within the limitations of the applied methodology. They dominated algal abundances in both ice and water, comprising $97 \%$ of ice algae and $98 \%$ of phytoplankton. A total of 74 diatom species were found: 71 in the ice, 36 in the water, and 42 in the sediment traps (Table 1). Fifty-one ice algal species could be distinguished using light microscopy, and were, therefore, used in 
abundance and species composition analyses; the rest were added from SEM and cleaned sample analyses. Flagellates contributed less than $3 \%$ to total abundance in any sample set; because of my focus of cells $>20 \mu \mathrm{m}$ and the limitations of my methodology, they were not identified.

Table 1. Diatom species inventory for Bering Sea ice, water and sediment trap samples. Bold indicates dominant species (contributing $>5 \%$ in at least one sample). "O" designates infrequent species appearing in two or fewer samples, "X" designates species appearing in more than two samples. "\$" designates species found only through SEM.

\begin{tabular}{|c|c|c|c|}
\hline Species & Ice & Water & Traps \\
\hline Actinocyclus curvatulus & $\$$ & & \\
\hline Actinoptychus senarius & & & $\mathrm{O}$ \\
\hline Amphiprora spp. & $\$$ & & $\mathrm{O}$ \\
\hline Attheya septentrionalis & $\$$ & & \\
\hline Bacteriosira bathyomphala & $\mathrm{O}$ & & \\
\hline Ceratoneis closterium & $\mathrm{X}$ & $\mathrm{X}$ & $\mathrm{X}$ \\
\hline Chaetoceros radicans & $\$$ & & \\
\hline Chaetoceros spp. & $\mathrm{X}$ & $\mathrm{X}$ & $\mathrm{X}$ \\
\hline Chaetoceros sp. 1 & $\$$ & & \\
\hline Cocconeis sp. 1 & & $X$ & $X$ \\
\hline Cocconeis sp. 2 & & & $X$ \\
\hline Coscinodiscus spp. & $\$$ & $\mathrm{O}$ & $\mathrm{O}$ \\
\hline Coscinodiscus sp. 1 & $\$$ & & \\
\hline Diploneis didyma & $\$$ & & \\
\hline Diploneis litoralis & $\$$ & & \\
\hline Entomoneis sp. 1 & $\mathrm{X}$ & $X$ & $X$ \\
\hline Entomoneis sp. 2 & $\mathrm{X}$ & & $\mathrm{O}$ \\
\hline Fallacia forcipata var. densestriata & $\$$ & & \\
\hline Fossula arctica & $\mathrm{X}$ & $X$ & $\mathrm{X}$ \\
\hline Fragilariopsis cylindrus & $\mathrm{X}$ & $\mathrm{X}$ & $X$ \\
\hline Fragilariopsis oceanica & $\mathrm{X}$ & $X$ & $X$ \\
\hline Gyrosigma sp. 1 & $\mathrm{X}$ & $\mathrm{X}$ & $\mathrm{X}$ \\
\hline Gyrosigma sp. 3 & $\mathrm{X}$ & $X$ & $\mathrm{O}$ \\
\hline Gyrosigma tenuissimum var. hyperborea & $\$$ & & \\
\hline Haslea spp. & $\mathrm{O}$ & & \\
\hline Melosira arctica & $\mathrm{O}$ & & \\
\hline Navicula algida & $\mathrm{X}$ & & \\
\hline Navicula directa & $\mathrm{X}$ & $\mathrm{X}$ & $\mathrm{X}$ \\
\hline
\end{tabular}


Table 1, continued

\begin{tabular}{|c|c|c|c|}
\hline Species & Ice & Water & Traps \\
\hline Navicula kariana var. detersa & $\mathrm{X}$ & & $\mathrm{X}$ \\
\hline Navicula menisculus & $\$$ & & \\
\hline Navicula pelagica & $\mathrm{O}$ & $X$ & \\
\hline Navicula septentrionalis & $\mathrm{X}$ & $\mathrm{O}$ & $\mathrm{X}$ \\
\hline Navicula sp. 1 & $\$$ & & \\
\hline Navicula superba & $\mathrm{O}$ & & \\
\hline Navicula transitans var. derasa & $\$$ & $\mathrm{O}$ & \\
\hline Navicula trigonocephala & $\mathrm{O}$ & & \\
\hline Navicula trigonocephala var. depressa & $\mathrm{O}$ & $\mathrm{O}$ & \\
\hline Navicula valida & $\mathrm{X}$ & $\mathrm{O}$ & $\mathrm{O}$ \\
\hline Navicula vanhoeffenii & $\mathrm{X}$ & & $\mathrm{X}$ \\
\hline Nitzschia angulata & $\$$ & & \\
\hline Nitzschia pellucida & $\mathrm{X}$ & $\mathrm{X}$ & $\mathrm{X}$ \\
\hline Nitzschia frigida & $\mathrm{X}$ & $\mathrm{X}$ & $\mathrm{X}$ \\
\hline Nitzschia lanceolata & $\$$ & & \\
\hline Nitzschia sigma & $\mathrm{X}$ & $\mathrm{O}$ & $\mathrm{X}$ \\
\hline Nitzschia sp. 1 & $\mathrm{X}$ & $\mathrm{O}$ & $\mathrm{X}$ \\
\hline Nitzschia sp. 2 & $\mathrm{X}$ & $\mathrm{O}$ & $\mathrm{X}$ \\
\hline Odontella aurita & $\mathrm{O}$ & & $\mathrm{O}$ \\
\hline Paralia sulcata & $\mathrm{O}$ & $\mathrm{X}$ & $X$ \\
\hline Pauliella taeniata & $\mathrm{X}$ & $X$ & $X$ \\
\hline Pinnularia quadratarea var. bicontracta & $\mathrm{X}$ & & $\mathrm{O}$ \\
\hline Pinnularia quadratarea var. capitata & $\mathrm{O}$ & & \\
\hline Pinnularia quadratarea var. constricta & $\mathrm{X}$ & $\mathrm{O}$ & $\mathrm{X}$ \\
\hline Pinnularia quadratarea var. cuneata & $\mathrm{O}$ & & \\
\hline Pinnularia quadratarea var. densestriata & $\mathrm{O}$ & & $\mathrm{O}$ \\
\hline Pinnularia quadratarea var. dubia & $\mathrm{X}$ & & $\mathrm{O}$ \\
\hline Pinnularia sp. 1 & $\mathrm{O}$ & & \\
\hline Pinnularia sp. 2 & $\mathrm{O}$ & & \\
\hline Pinnularia sp. 3 & $\mathrm{O}$ & & \\
\hline Pinnularia sp. 4 & $\mathrm{X}$ & $X$ & $\mathrm{O}$ \\
\hline Pinnularia sp. 5 & $\mathrm{O}$ & $\mathrm{O}$ & \\
\hline Plagiotropis spp. & $\$$ & & \\
\hline Pleurosigma spp. & $\mathrm{X}$ & $\mathrm{O}$ & $\mathrm{X}$ \\
\hline Pleurosigma teuniforme & $\mathrm{O}$ & $X$ & $\mathrm{X}$ \\
\hline Pseudogomphonema arctica & $\$$ & & \\
\hline Pseudogomphonema groenlandicum & $\mathrm{X}$ & $\mathrm{O}$ & $\mathrm{O}$ \\
\hline
\end{tabular}


Table 1, continued

\begin{tabular}{|l|c|c|c|}
\hline Species, continued & Ice & Water & Traps \\
\hline Pseudogomphonema septentrionale & $\mathrm{X}$ & $\mathrm{X}$ & $\mathrm{X}$ \\
Pseudogomphonema septentrionale var. angustatum & $\$$ & & \\
Pseudo-nitzschia delicatissima & $\mathrm{X}$ & $\mathrm{X}$ & $\mathrm{X}$ \\
Pseudo-nitzschia seriata & $\mathrm{X}$ & $\mathrm{X}$ & $\mathrm{X}$ \\
Stenoneis inconspicua & $\mathrm{O}$ & & \\
Thalassionema nitzschioides & $\mathrm{O}$ & $\mathrm{X}$ & $\mathrm{X}$ \\
Thalassiosira hyalina & $\mathrm{X}$ & $\mathrm{X}$ & $\mathrm{X}$ \\
Thalassiosira nordenskioeldii & $\mathrm{S}$ & $\mathrm{O}$ & $\mathrm{O}$ \\
Thalassiosira spp. & $\mathrm{X}$ & $\mathrm{X}$ & $\mathrm{X}$ \\
Unidentified flagellates & $\mathrm{X}$ & $\mathrm{O}$ & $\mathrm{X}$ \\
& & & \\
\hline
\end{tabular}

Only 15 of the 57 species quantified using light microscopy contributed more than $5 \%$ to the total abundance in any one sample and were considered "abundant" (Table 1). Of the remaining species, 11 were very rare and appeared in one or two samples only. The algal abundances in ice, water and sediment trap samples were all dominated by Fragilariopsis spp. with $28 \%, 37 \%$ and $52 \%$, respectively. All of the abundant and frequently occurring species (those found in over $50 \%$ of the samples by sample set) were found within all three sample sets. No numerically important species was associated exclusively with ice, water or sediment trap samples.

Rarefaction curves were used to extrapolate the actual species richness in each sample set (Fig. 4). Species richness in the ice was estimated at 63 species maximum, reached at 80 samples, while in the water and sediment traps the asymptote was reached at 50 samples, with a total of 43 species in the water and 48 in the traps. Including the species identified from the ice based on the SEM and cleaned sample analysis, the estimation of species richness in ice increased to 82 at 80 samples. 


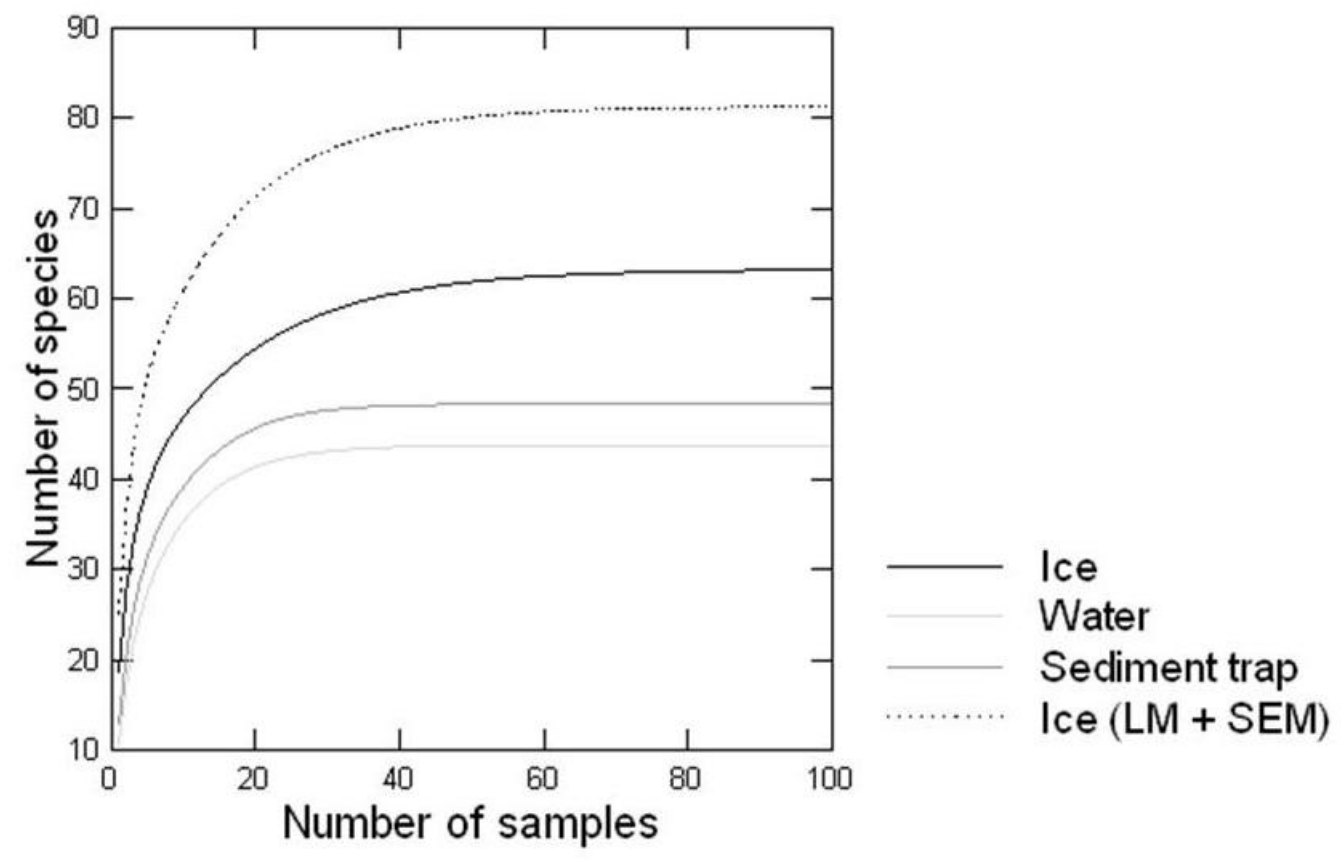

Figure 4. Rarefaction curves showing extrapolated species richness in ice, water and sediment trap samples given 100 samples. Solids lines indicate species richness based on light microscope analysis (ice samples $n=20$, water samples $n=13$, sediment trap samples $n=20$ ). Dotted line indicates species richness based on light microscope (LM) and scanning electron microscope $(\mathrm{SEM})$ analysis (ice samples $\mathrm{n}=10$ ).

\section{Abundance and vertical flux rate}

The abundance of ice algae (Table 2) increased significantly between the ice growth and the ice melt periods (t-test, $\mathrm{p}<0.05$ ). During ice growth, ice algal abundance ranged from $1.86 \mathrm{x}$ $10^{4}$ to $7.40 \times 10^{7}$ cells $1^{-1}$, with an average of $1.56 \times 10^{7}$ cells $1^{-1}$; during ice melt, ice algal abundance ranged from $1.17 \times 10^{7}$ to $1.39 \times 10^{8}$ cells $1^{-1}$, with an average of $5.85 \times 10^{7}$ cells $1^{-1}$. Ice algal abundance was not significantly correlated to either day length or day of the year $(\mathrm{p}>0.05)$. Abundances in the ice were significantly higher than those in the water $(\mathrm{t}$-test, $\mathrm{p}<0.05)$; on average, ice algal abundance was three orders of magnitude higher than that of the phytoplankton. Phytoplankton abundance did not change significantly between periods (t-test, p>0.05) but was highly variable among stations, ranging from $4.00 \times 10^{2}$ to $6.50 \times 10^{4}$ cells $^{-1}$, with an overall average of $1.29 \times 10^{4}$ cells $1^{-1}$ across both periods. The vertical flux beneath the 
ice was significantly higher during ice melt compared to ice growth ( $\mathrm{t}$-test, $\mathrm{p}<0.05)$. During ice growth, flux rates ranged from $3.63 \times 10^{5}$ to $1.39 \times 10^{8}$ cells $\mathrm{m}^{-2}$ day $^{-1}$, with an average of $4.16 \mathrm{x}$ $10^{7}$ cells $\mathrm{m}^{-2}$ day $^{-1}$; during ice melt, flux rates ranged from $1.08 \times 10^{7}$ to $3.67 \times 10^{8}$ cells m$^{-2}$ day $^{-}$ 1 , with an average of $1.19 \times 10^{8}$ cells $\mathrm{m}^{-2}$ day $^{-1}$. There was no significant difference in ice algal abundance or vertical flux rate between years ( $p>0.05$ for both comparisons). Comparisons of phytoplankton abundance could not be made as water sampling dates did not overlap between years.

Table 2. Mean algal characteristics during ice growth and ice melt periods. Mean algal abundance in ice and water samples (cells $1^{-1}$ ) and mean vertical flux rate beneath the ice (cells $\mathrm{m}^{-2}$ day $\left.^{-1}\right)$ during ice growth and ice melt periods. Coefficient of variation $(\mathrm{CV}=\mathrm{SD} / \mathrm{mean})$ reported as percent of the mean. Mean standing stock (S.S.) in the ice (cells $\mathrm{m}^{-2}$ in the bottom 2 $\mathrm{cm}$ ) and the water (cells $\mathrm{m}^{-2}$ in the upper $5 \mathrm{~m}$ ) during ice growth and ice melt periods, as well as mean percent of the standing stock sinking per day (\% S.S. sinking day ${ }^{-1}$ ). Proportion of abundance comprised of empty cells in each sample set during ice growth and ice melt periods. Chlorophyll $a$ concentrations ( $\mu \mathrm{g}$ chl- $a \mathrm{~m}^{-2}$ for ice and water) and flux rate (mg chl- $a \mathrm{~m}^{-2}$ day $^{-1}$ for traps), and estimated chl- $a$ cell $^{-1}$ within each sample set during ice growth and ice melt periods.

\begin{tabular}{|c|c|c|c|c|c|c|c|}
\hline & \multicolumn{6}{|c|}{ Ice growth } & \multirow[b]{2}{*}{$\begin{array}{c}\text { pg } \\
\text { Chl-a } \\
\text { cell }^{-1 *}\end{array}$} \\
\hline & $\begin{array}{l}\text { Mean } \\
\text { cells }\end{array}$ & $\mathrm{CV} \%$ & Mean S.S. & $\begin{array}{c}\% \text { S.S. } \\
\text { sinking } \\
\text { day }^{-1}\end{array}$ & $\begin{array}{c}\% \\
\text { Empty } \\
\text { cells }\end{array}$ & Chl-a* & \\
\hline Ice & $1.56 \times 10^{7}$ & 158.09 & $3.46 \times 10^{8}$ & 75.94 & 0.91 & 113.01 & 6.05 \\
\hline Water & $5.72 \times 10^{3}$ & 141.79 & $3.47 \times 10^{7}$ & 202.01 & 17.41 & 0.14 & 23.08 \\
\hline Traps & $4.16 \times 10^{7}$ & 131.93 & -- & -- & 19.23 & 1.10 & 32.51 \\
\hline
\end{tabular}

\section{Ice melt}

\begin{tabular}{lccccccc} 
& $\begin{array}{c}\text { Mean } \\
\text { cells }\end{array}$ & CV\% & Mean S.S. & $\begin{array}{c}\text { \% S.S. } \\
\text { sinking } \\
\text { day }^{-1}\end{array}$ & $\begin{array}{c}\text { pg } \\
\text { Empty } \\
\text { cells }\end{array}$ & $\begin{array}{c}\text { Chl- } a \\
\text { ( }\end{array}$ & $\begin{array}{c}\text { Chl- } a \\
\text { cell }^{-1 *}\end{array}$ \\
\hline Ice & $5.85 \times 10^{7}$ & 85.97 & $1.17 \times 10^{9}$ & 21.7 & 0.05 & 432.23 & 7.39 \\
Water & $2.45 \times 10^{4}$ & 99.83 & $1.22 \times 10^{8}$ & 368.06 & 0.76 & 0.61 & 25.12 \\
Traps & $1.20 \times 10^{8}$ & 112.94 & -- & -- & 3.91 & 3.08 & 25.76
\end{tabular}

${ }^{*}$ Chlorophyll $a$ concentrations courtesy of R. Gradinger, unpublished data. 
During the ice growth period, the vertical flux represented the sinking of an average of $76 \%$ of the ice algal standing stock in the bottom $2 \mathrm{~cm}$ per day, or an average of over $200 \%$ of the phytoplankton standing stock in the upper $5 \mathrm{~m}$ of the water column, assuming that the phytoplankton abundance throughout the upper $5 \mathrm{~m}$ was the same as measured at $5 \mathrm{~m}$ depth, and assuming a 100\% contribution to the flux of cells from either the ice or the water (Table 2). During the ice melt period, the vertical flux rate represented the sinking of $22 \%$ of the ice algal standing stock or $368 \%$ of the phytoplankton standing stock. These proportions were highly variable by station, ranging from $<1$ to $150 \%$ of the ice algae and 10 to $1500 \%$ of the phytoplankton across both periods. The proportions for ice algae and phytoplankton, respectively, did not differ significantly between ice growth and melt periods ( $t$-test, $\mathrm{p}>0.05$ for both comparisons), nor did they differ between years (t-test, $\mathrm{p}>0.05$ for both comparisons).

There was no significant correlation between ice algal abundance, phytoplankton abundance, or vertical flux rate and the environmental variables measured (ice concentration, primary ice type, ice thickness, snow depth, nutrient concentrations in the water, and day length) during either ice growth or ice melt periods (BEST-BIOENV, p>0.05 for all comparisons).

\section{Fate of ice algae}

During ice growth, the species composition in the ice was significantly different from that in the water and the traps based on relative species abundances (PERMANOVA, $<<0.05$ for both comparisons). There was no difference in the composition in the water and the traps during ice growth or ice melt (PERMANOVA, p>0.05 for both comparisons). However, during ice melt, the composition in the ice and the water were no longer significantly different (PERMANOVA, $\mathrm{p}>0.05)$ while the ice algal composition remained different from that found in the trap samples (PERMANOVA, $\mathrm{p}<0.05$ ). When the species compositions were visualized using an MDS plot, these differences could be seen among sample sets (Fig. 5); the stress values indicate a reasonably good representation of the data in two dimensional space (Clarke 1993). 

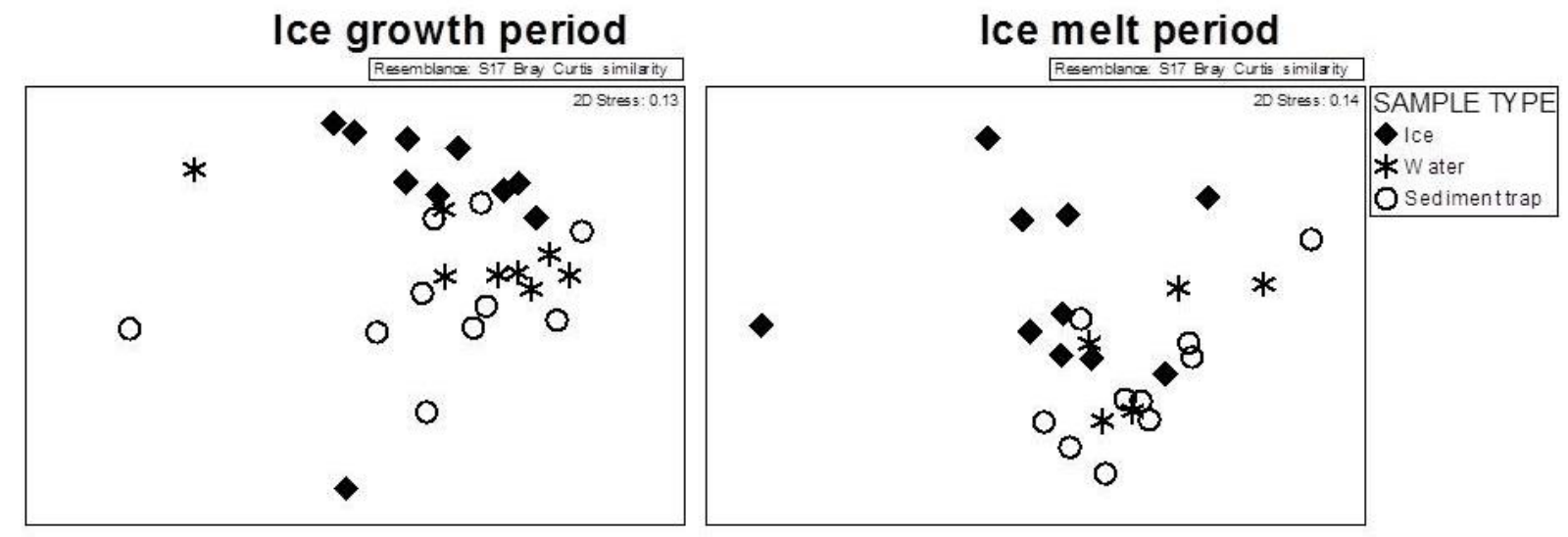

Figure 5. Multi-dimensional scaling plots of the relative species abundance (as \% of total) in ice, water and sediment trap samples. Left panel shows similarity of samples during the period of ice growth, right panel shows similarity of samples during the period of ice melt.

Only six species were individually responsible for $5 \%$ or more of the dissimilarity in community composition between sample sets based on SIMPER analyses, and, therefore, were used for comparisons between sample sets. During ice growth, these species included Fragilariopsis spp., Nitzschia frigida, Paralia sulcata and Chaetoceros spp., which together contributed to over half of the difference among sample sets (SIMPER, 57\%). During melt, the same species were important with the exception of Chaetoceros spp., while Pauliella taeniata and Fossula arctica also contributed substantially; together these five species were responsible for $72 \%$ of the difference among sample sets.

When the relative proportions of the key species identified as driving the dissimilarity among sample sets were individually compared between ice, water and traps, I found several differences (Fig. 6). During the ice growth period, there were significantly higher proportions of Chaetoceros spp. and Paralia sulcata in the water and traps as compared to the ice (ANOVA, $\mathrm{p}<0.05$ for both comparisons); when all centric diatoms were grouped, there were significantly higher proportions in the water and traps than in the ice (ANOVA, $\mathrm{p}<0.05$ for both comparisons). There were also significantly lower proportions of Nitzschia frigida in the water and traps as compared to in the ice during the ice growth period (ANOVA, $\mathrm{p}<0.05$ ). During the ice melt 
period, once again there were significantly higher proportions of centric diatoms and lower proportions of $N$. frigida in the water and traps when compared to the ice (ANOVA, $\mathrm{p}<0.05$ for all comparisons). There were also significantly higher proportions of those diatoms forming ribbon-colonies (i.e., Fragilariopsis spp., Fossula arctica, Pauliella taeniata) in the traps than in the ice (ANOVA, $\mathrm{p}<0.05$ ).

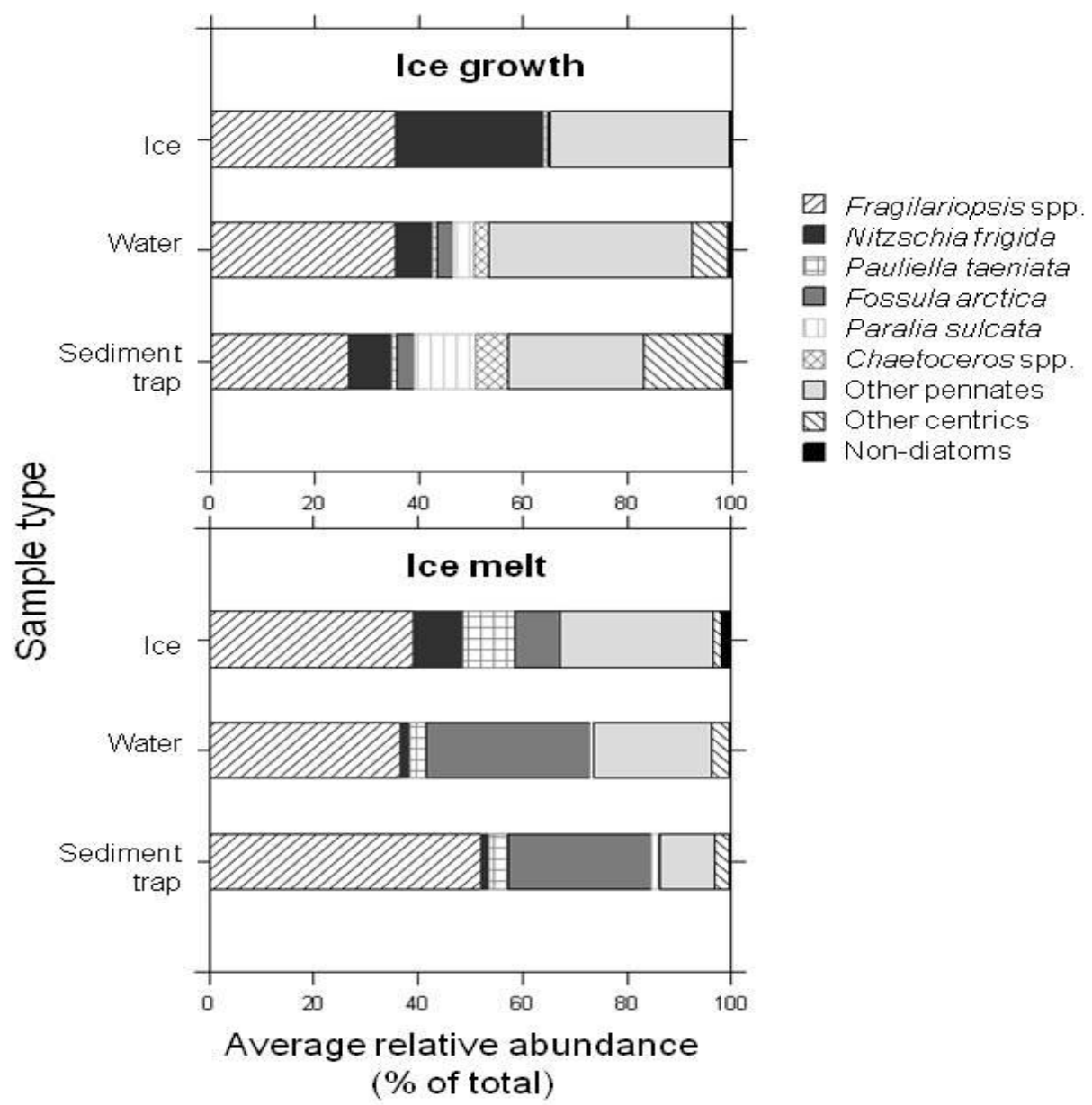

Figure 6. Relative abundance (\% of total) of species in ice, water and sediment trap samples. Species shown are those contributing $>5 \%$ to the dissimilarity between sample sets based on SIMPER analysis. Upper section shows species composition during the ice growth period, lower section shows species composition during the ice melt period. 
I looked for correlations in the proportion of dominant species between sample sets using a Mantel's test. During both periods, the species composition in the water and the traps was significantly correlated $(\mathrm{r}=0.30, \mathrm{r}=0.34$, for ice growth and ice melt, respectively; $\mathrm{p}<0.05$ for both correlations). During ice melt, the composition in the ice and the water was also significantly correlated $(\mathrm{r}=0.41, \mathrm{p}<0.05)$. No other correlations between sample sets were significant.

\section{Discussion}

I present the first quantitative assessment of the Bering Sea ice algal community composition and the first direct examination of the connection between algal communities from the ice and water and vertical flux beneath the ice in this region. This study showed a highly abundant and diverse ice algal community, coupled with a very similar phytoplankton community that remained at low abundances throughout the spring. The similarity of species between ice and water is also reflected in the composition of the sediment traps, which captured a substantial vertical flux of cells even in early spring. I will first discuss the environmental conditions found during the course of this study, which occurred during a cold period in the Bering Sea. Secondly, I will describe the diversity in the ice, water and sediment traps in comparison to other subarctic and Arctic regions. Thirdly, I will compare the abundance of cells in these sample sets and describe how they changed between ice growth and ice melt periods in the spring. And finally, I will discuss the vertical flux of cells beneath the ice in the context of the ultimate fate of ice algae in the Bering Sea.

\section{Environmental conditions}

The environmental conditions in the Bering Sea were significantly different during the periods I defined as ice growth and ice melt, revealing a transition from thick first-year ice in the early spring to thinner, more variable ice types from mid-April to May. Throughout both periods the conditions reflected the cold climate and heavy ice cover in the Bering Sea during 2008 and 
2009 (Wendler et al. 2013). Ice cover was extensive at all stations sampled, with only two stations displaying less than $75 \%$ coverage. Although ice thickness significantly decreased from the period of ice growth to ice melt, it remained substantial throughout the spring with a minimum of $0.40 \mathrm{~m}$; it should be noted that this may also reflect the non-random nature of station selection, which favored thick, stable ice floes for safety reasons and, therefore, may not be fully representative of the entire region. The thick ice coupled with undiminished snow cover resulted in low light levels under the ice, averaging $10 \mu \mathrm{mol} \mathrm{m} \mathrm{sec}^{-1}$, which approached the minimum for ice algal growth $\left(\sim 1 \mu \mathrm{mol} \mathrm{m} \mathrm{m}^{-2} \mathrm{sec}^{-1}\right.$; Mock and Gradinger 1999). Surface water temperatures were near freezing throughout the spring. The maximum ice extents during 2008 and 2009 were among the greatest since the 1970's, extending south of St. Paul Island and reaching a maximum in the southern Bering Sea at the end of March (Sigler and Harvey 2010). These characteristics made the Bering Sea essentially an Arctic system during the spring.

Our sampling occurred during a recent cold period in the Bering Sea which started in 2007, characterized by extensive sea ice extent and late ice melt. The five years prior (20012005) were warm, with low ice extent in the spring and earlier ice retreat by as much as six weeks (Overland et al. 2009; Stabeno et al. 2012b). These regular fluctuations in Bering Sea ice and water conditions are primarily the result of shifts in wind direction during the spring. During cold years, strong northerly winds draw cold Arctic air into the Bering Sea, delaying ice melt and causing ice to be advected farther south across the shelf; during warm years, weaker easterly winds bring in warmer air and fail to maintain ice on the southern shelf regions (Stabeno et al. 2012b). Currents also differ between cold and warm years, with westward currents during the former bringing cold coastal water across the shelf, while a more northward flow during the latter draws up warmer water from the Alaska Peninsula (Stabeno et al. 2012b).

The conditions in the Bering Sea during this study were similar to those found in other subarctic seas, e.g., the Sea of Okhotsk on the Pacific side and the Labrador and Barents seas on the Atlantic side. These regions are transition zones between Arctic and temperate climates, and are characterized by locally formed first-year ice 1-2 m thick, which reaches its maximum extent in March, then completely retreats during the ice-free summer months (Wang et al. 2007). In the spring this creates a highly dynamic ice-edge zone that can be very productive. Compared to other subarctic regions, the Bering Sea has high nutrient concentrations in the water due to the 
input of nutrient-rich water from the Gulf of Anadyr and, to a lesser extent, the Gulf of Alaska (Loughlin and Ohtani 1999). The Bering Sea shelf is also shallower than most other subarctic seas (Wang et al. 2007), allowing for the close coupling between benthic and pelagic realms (Grebmeier 1988).

Ice conditions in the high Arctic are quite different from those in the subarctic Bering Sea, with near-constant ice cover in many areas and a significant proportion of multi-year ice (Thomas and Dieckmann 2003); recently, the Arctic has seen a dramatic decline in sea ice extent, unlike in the Bering Sea where ice extent has not significantly changed over the past decades (Brown and Arrigo 2012). This stability in Bering Sea ice is due to its wind-driven ice formation, by which strong northerly wind causes a "conveyor belt" of ice formed in the northern coastal regions and that is then advected south over the shelf (Pease 1980). Although there is high inter-annual variation in winter winds, there has been no major shift in wind direction over the past decades (Brown and Arrigo 2012). However, the recent increase in Arctic winter air temperatures, which results in a warmer northerly wind, may ultimately affect ice formation in the Bering Sea, as Bering Sea ice formation is driven by atmospheric processes in the Arctic.

\section{Diversity of ice algae and phytoplankton}

Traditionally, diversity in the Arctic flora and fauna was believed to be quite low relative to temperate and tropical regions, due to the harsh climate and comparative instability of environmental conditions (Sanders 1968). However, recent studies show that among marine microalgae the diversity in the Arctic is in fact higher than predicted. In a recent inventory, Poulin et al. (2011) compiled a list of 2106 algal species in the Arctic (1027 in the ice, 1874 in the water), which is a large number considering a current inventory of only approximately 5,000 phytoplankton species worldwide (Tett and Barton 1995).

The recent compilation of ice algal and phytoplankton diversity underscored another important aspect of Arctic algal diversity, which is the regional disparity of investigations. Some regions (e.g., Hudson Bay, the Norwegian Barents Sea, the Beaufort and Chukchi seas) have been thoroughly explored, with each region subject to over a dozen studies documenting algal diversity, while other Arctic and subarctic regions remained virtually unexamined. The Bering 
Sea is one such notable case. Only a sparse handful of surveys have investigated the diversity of Bering Sea phytoplankton, and aside from the limited examination of two ice cores taken in the 1970's (Schandelmeier and Alexander 1979), to date there has been no description ice algal diversity in the Bering Sea.

The diversity that I found in the Bering Sea ice algae was much higher than these limited earlier investigations suggested. In addition to the 15 species from those surveys (with the exception of Ditylum brightwellii and Actinoptychus undulatus; Schandelmeier and Alexander 1979), I found 58 others that have never before been recorded in the Bering Sea (Table 1). This large increase in species richness is due to the ten-fold higher number of samples processed, and the addition of scanning electron microscopy in this study, which increased my species inventory by a third compared with traditional light microscopy alone. Extrapolations of species richness using a rarefaction curve further increased this number to a final estimate of 82 species (Fig. 4).

A recent study applied molecular techniques to ice algal communities in the Bering Sea, with a focus to assess zooplankton grazing pressure rather than diversity in the winter/spring of 2010 (Durbin and Casas 2014). Unfortunately, loss of samples forced the authors to use Lugolsfixed algae, which are not ideal for molecular analysis; they identified less than a third of the number of diatom species found in this study (23 vs. 71, Durbin and Casas 2014). Interestingly, eleven of these were not identified in my study; while there may have been differences in the community composition between years, many of these species were among those taxa identified in my study only to genus (e.g., Navicula spp., Nitzschia spp.), suggesting that molecular techniques could be useful for further enhancing our understanding of Bering Sea algal diversity.

The inventory by Durbin and Casas (2014) also included several non-diatom ice algae including two dinoflagellates, a cryptophyte, and five cercozoans, whereas I focused solely on diatom species $>20 \mu \mathrm{m}$ and excluded the identification of any flagellate species, as morphological taxonomy using light microscopy is most accurate for this size class of diatom taxa. A recent review suggested that in the Alaskan Arctic small cells $(<20 \mu \mathrm{m})$ contribute on average only $4 \%$ to the species richness of ice algae, and flagellates contribute less than $10 \%$ (Poulin et al. 2011).

The diversity of ice algae across the Arctic is highly variable and likely still undersampled; with 71 species, the observed species richness of diatoms in the Bering Sea ice in this 
study was higher than the species richness of diatoms in the Kara Sea (11 species; Druzhkov et al. 2001), the Laptev Sea (19 species; Tuschling et al. 2000) and the Arctic Ocean (25 species; Booth and Horner 1997), but lower than in the East Siberian Sea (115 species; Okolodkov 1993), the Canadian Arctic (197 species; Hsiao 1983), and the Chukchi Sea (251 species; von Quillfeldt et al. 2003). It should be noted, however, that species richness estimates depend greatly on the sampling effort and the methodology of identification, as demonstrated in this study where species richness increased substantially in the ice when a) extrapolated over a higher number of samples and b) analyzed with the addition of scanning electron microscopy (Fig. 4). Therefore, caution should be used when comparing species richness across studies.

The Bering Sea ice algal community was composed of both polar and polar/temperate species, but was more similar to ice algal communities in Arctic regions than to other subarctic seas. In the Okhotsk Sea - a subarctic sea that lacks the Bering Sea's Arctic connection- the spring sea ice is overwhelmingly dominated by centric diatoms common to the Pacific (e.g. Odontella aurita, Thalassiosira punctigera, Detonula confervacea; McMinn et al. 2008), which were rare or absent in the Bering Sea. The brackish Baltic Sea has a more similar community of polar diatoms through its relic connection to the Arctic, but the dominant Bering Sea taxa (i.e., Fragilariopsis spp.) is not common there (Ikavalko and Thomsen 1997; Haecky et al. 1998). The Barents Sea also shares many polar species with the Bering Sea, but its dominant species (i.e., Nitzschia pomare, Synedropsis hyperborea, and Chaetoceros spp.; Falk-Petersen and Sargent 1998; Hegseth 1998) only rarely appeared in Bering Sea ice. The high abundance of Nitzschia frigida and Fragilariopsis spp. in the Bering Sea is characteristic of many Arctic regions, including the Beaufort Sea (Horner and Schrader 1982), the Canadian Arctic (Fortier et al. 2002; Melnikov et al. 2002; Tremblay et al. 2006), and the Norwegian Sea (McMinn and Hegseth 2004; Leu et al. 2010). However, there was one major difference between Bering Sea and other Arctic ice algae: the near-absence of Melosira arctica, a chain-forming centric diatom primarily found on multi-year ice that is ubiquitous in nearly all Arctic regions, and can contribute a substantial amount to the overall biomass of Arctic ice algal communities (e.g. Poulin et al. 2014). It should be noted that $M$. arctica was found in high abundance during a BEST cruise in Bering Sea in May/June 2010, suggesting possible seasonal or interannual variability in its occurrence in this region (Wang et al. 2014). The Bering Sea also appears to lack the ice- 
associated amphipods that are endemic to the Arctic (K. Iken, unpublished data), and are a major part of the sympagic food web there (Iken et al. 2005).

Among the phytoplankton, I found a subset of the same species as in the ice, but there was lower species richness in the water at every station. Many previous studies have found similarly lower diversity in the sub-ice phytoplankton as compared to the overlying ice (e.g., Margalef 1977; Horner 1985; Hsiao 1992). With a total of 36 species, the species richness of diatoms in the Bering Sea phytoplankton was higher than found beneath the ice during the spring in the Kara Sea (8 species; Druzhkov et al. 2001) and the Arctic Ocean (30 species; Booth and Horner 1997), but lower than in northern Baffin Bay (70 species; Lovejoy et al. 2002); although again, comparisons should be made with caution due to the differences in sampling effort and methodology. Studies covering different time spans also make comparisons difficult, as phytoplankton communities undergo extensive seasonal succession, and annual species richness at a single location can exceed 240 species (e.g., Hsaio 1983).

The very high similarity between the sea ice and phytoplankton algal species indicated that the spring phytoplankton originated from the ice, as only one (Cocconeis sp. 1) of the 36 species found in the water was not also present in the ice. A 1977 survey of the Bering Sea phytoplankton (Schandelmeier and Alexander 1979) found similar species in March to those in this study, although they recorded only 12 species. More recent work has also noted the presence of common ice species (e.g. Fragilariopsis spp., Nitzschia spp.) in the sub-ice phytoplankton in the Bering Sea (Sherr et al. 2013). The duality of ice algal and phytoplankton species is recurring: because many subarctic and Arctic regions including the Bering Sea are ice-free in the summer, new sea ice must be seeded with biota from existing phytoplankton populations (Ikavalko and Gradinger 1998; Riedel et al. 2007). Organisms are incorporated into the ice during its earliest formation stages, scavenged from the water by rising frazil ice (Ikavalko and Gradinger 1998), or lifted from the benthos by deep-forming frazil or anchor ice (Reimnitz 1992; Reimnitz and Clayton 1993). There are few truly endemic ice algal species in the Arctic (e.g., Nitzschia frigida, N. promare, Melosira arctica; Ambrose et al. 2005; Poulin et al. 2011) and of these, only $N$. frigida is abundant in the Bering Sea. $N$. frigida has previously been recorded among Arctic phytoplankton (e.g., Booth 1984; Druzhkov et al. 2001), but always as a remnant from the ice. Fragilariopsis cylindrus, another dominant species among the Bering Sea ice algae, 
has long been used as a paleo-indicator of sea ice; however, it has been found in the water column in entirely ice free areas (von Quillfeldt 2004, and references therein) and thus is more accurately viewed as a cold water species.

The species composition of the Bering Sea phytoplankton was unique from other Arctic spring phytoplankton communities in its degree of similarity to the ice algal community, a similarity that appears to vary in space and time. Spring phytoplankton communities in the Bering Sea vary considerably across the shelf, with the dominance of ice algal species increasing with increased proximity to the ice edge (Schandelmeier and Alexander 1981). The similarity to ice algal communities is short-lived, and by late spring/early summer the phytoplankton composition in the Bering Sea shifts to a more centric-dominated community (Taniguchi et al. 1976). Ice-associated species are replaced by pelagic centric diatoms such as Thalassiosira nordenskioeldii and T. decipiens, which were rare or absent during this study, although some pennate species (e.g. Fossula arctica, Navicula spp.) continue to be found in high abundance in some parts of the water column (Taniguchi et al. 1976). This transition is typical of subarctic and Arctic phytoplankton (e.g. Michel et al. 1997; Haecky et al. 1998; Tamelander and Heiskanen 2004), which classically undergo a succession from the chain-forming pennate species that dominate the ice algae, followed by a more centric-dominated community later in the season (von Quillfeldt 2000). However, even in other early-stage Arctic phytoplankton communities (Legendre et al. 1981; Horner and Schrader 1982; Haecky et al. 1998) none matched the degree of overlap between the ice algal and phytoplankton species as in the Bering Sea in this study.

In the sediment trap samples, the species composition was very similar to that found in both ice and water. Of the 42 species that were identified from the traps, all but two were present in the ice-Actinoptychus undulatus and Cocconeis costata - each of which was found only once as a single individual. A. undulatus was previously recorded in Bering Sea ice (Schandelmeier and Alexander 1979) so it may have occurred there in low abundance in this study, while $C$. costata may have been advected from elsewhere on the shelf, or possibly resuspended from the shallow sediments. Over three-quarters of the rare ice algal species (those appearing only in one or two samples) did not appear in the traps, suggesting that the short (4-6 hour) deployment time may not have been sufficient to capture the rare species. However, as all abundant species were 
found throughout all three sample sets, there appears to be no strong separation between the ice, water and vertical flux in terms of species inventories during the spring.

\section{Abundance of ice algae and phytoplankton}

The abundance of ice algae in the Bering Sea was very high throughout the entire spring sampling period, so ice algal production must begin before mid-March. Abundance increased from the period of ice growth to the period of ice melt; however, there was no significant relationship between any physical factors measured in this study and the abundance of ice algae. The absence of a clear relationship between environmental variables and abundance may be due to the high variability in both data sets, as observed previously in the Chukchi Sea, where no relationship was found between ice algal coverage and any large scale environmental variable (Ambrose et al. 2005). It is also possible that other factors influenced ice algal abundance that were not measured in this study, such as sub-ice topography (Melnikov 1987), rate of ice growth and melt (Legendre et al. 1991), distance from the edge of the ice floe (Ambrose et al. 2005), or the local ice conditions in the days prior to sampling.

The abundance of ice algae during ice melt was among the highest reported in both subarctic and Arctic regions, although abundances at individual stations from the Canadian Arctic and the Beaufort Sea surpassed even the highest abundance found in this study ( Hsiao 1980; Horner and Schrader 1982). Those stations were sampled during late May, and ice algal abundances in the Bering Sea may have been similarly high that late in the spring. The high abundance in the Bering Sea ice may be due to the nutrient-rich underlying water, which is higher than in most other subarctic and Arctic seas (e.g., Gradinger 2009).

Phytoplankton abundance was very low throughout both spring periods, and did not significantly increase from the period of ice growth to ice melt. Abundance was three orders of magnitude below levels previously recorded on the Bering Sea shelf in May (Taniguchi et al. 1976). Although the spring ice-edge phytoplankton bloom typically begins the last week in April in the Bering Sea (Sigler et al. 2014), the cold springs in 2008 and 2009 retarded the development of the bloom, postponing it until late May and early June based on chlorophyll $a$ concentrations (Sherr et al. 2013). The key drivers of phytoplankton blooms in subarctic and 
Arctic seas are 1) sufficient light for algal growth, and 2) sufficient stratification to maintain cells above the $1 \%$ PAR level, both of which are accomplished during ice retreat (Legendre et al. 1981). However, the ice did not retreat substantially during the periods that were sampled during this study. Throughout the spring the mixed layer depth remained well below the $1 \%$ PAR level, which was shallow due to thick ice and snow cover (Fig. 7; M. Lomas, unpublished data). The consistently high surface salinity during both ice growth and ice melt periods indicated that there was insufficient melt water to drive any strong density-dependent stratification in the water column, and the lack of change in surface nutrient concentrations between ice growth and ice melt periods confirms that the phytoplankton bloom had not yet occurred.

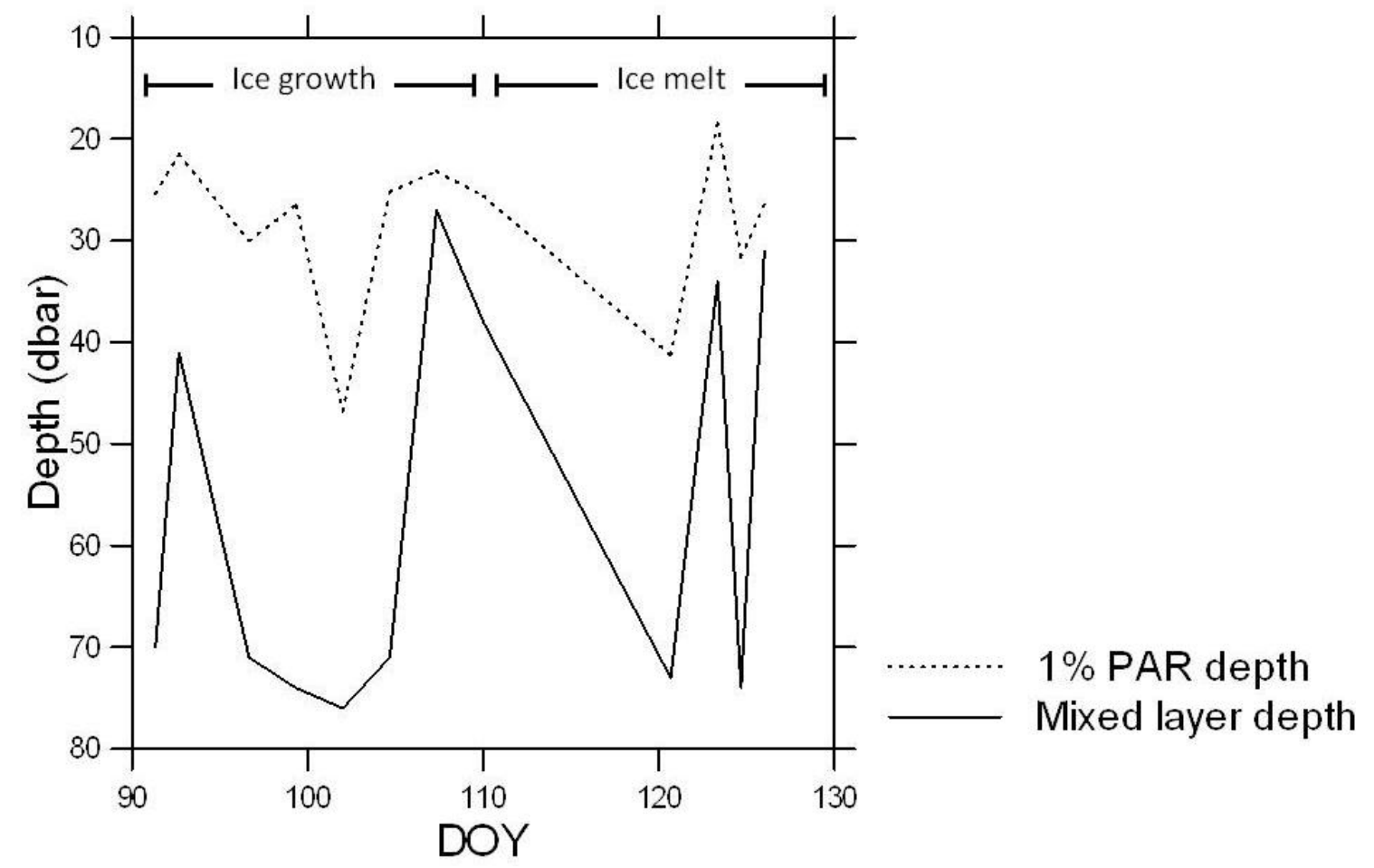

Figure 7. Comparison of the euphotic zone (as indicated by the $1 \%$ PAR depth) and the mixed layer depth in the Bering Sea during ice growth and ice melt periods in 2008 and 2009 (M. Lomas, unpublished data). 
In some Arctic regions, large phytoplankton blooms have been found under full ice cover, which can match or even exceed spring phytoplankton bloom chlorophyll $a$ concentrations (e.g., Gradinger 1996, Fortier et al. 2002, Arrigo et al. 2012, Arrigo et al. 2014). I found no evidence for this phenomenon in this study. One key difference is that regions with large under-ice phytoplankton blooms are all characterized by extensive coverage of melt ponds on the surface of the ice. Melt ponds allow approximately four times the light penetration as compared to bare ice (Arrigo et al. 2012), while snow covered ice allows even less light to reach the underlying water. No melt ponds were recorded around the stations sampled in the Bering Sea during this study, and snow cover was consistently thick, preventing the sufficient penetration of light beneath the ice that would be required to support such large under-ice phytoplankton blooms.

\section{Vertical flux of algal cells}

There was a large vertical flux of algal cells beneath the ice throughout the spring, which increased significantly during the ice melt period. Prior to ice melt, most seasonally ice-covered regions have minimal vertical flux under the ice (e.g., Bauerfeind 1994; Michel et al. 1997; Olli et al. 2002); however, there can be high variability in the timing and intensity of flux depending on meteorological conditions (Fortier et al. 2002; Michel et al. 2006). The high vertical flux rate and low phytoplankton abundance during ice growth in the Bering Sea indicated that there was an input of cells from the ice into the water prior to ice melt. The observed vertical flux would have required on average the sinking of over $200 \%$ of the phytoplankton standing stock in the upper $5 \mathrm{~m}$ per day to support it. As phytoplankton growth rates in the Bering Sea during ice growth are low ( $<0.1 \mathrm{~d}^{-1}$; Moran et al. 2012), such high flux rates would quickly exhaust the standing stock without input from another source. During the ice growth period, the ice algal standing stock in the bottom $2 \mathrm{~cm}$ of sea ice alone was on average several times the size of the phytoplankton standing stock in the upper $5 \mathrm{~m}$, so the release of cells from this domain could more easily support the observed flux rates.

During the ice growth period, the release of ice algal cells likely resulted from periodic ablation of the fragile bottom layer of the ice, which contains the bulk of the ice algal biomass. 
Ice algae can be present in a loosely attached under-ice film (Ambrose et al. 2005), so slight melting from the heat flux from tidal flow or ocean swells could easily dislodge cells (Pogson et al. 2011). The accumulation of ice algae and subsequent conversion of solar radiation into heat has also been shown to cause local melting of the ice, resulting in the release of ice algae into the water (Zeebe et al. 1996). Such sporadic release would explain the high variability in flux rates that I found among stations. The release of dead algal cells from the ice through brine drainage could also contribute to the vertical flux, and would explain the relatively higher proportion of empty diatom frustules found in the trap samples compared to the ice (Table 2). These empty frustules in the ice result from microzooplankton grazing, which was high in the Bering Sea at the time of this study (Sherr et al. 2013), and also from parasitism by chytrids, which was observed in the ice at several stations (A. Szymanski, unpublished data).

The early spring vertical flux of cells is an important source of food for benthic organisms. The shallow Bering Sea shelf has tight pelagic-benthic coupling that supports large benthic communities (Grebmeier 1988). Sediment oxygen uptake under full ice cover in March showed significant metabolic activity of benthic organisms, indicating that the Bering Sea benthos has an active community even in early spring (Cooper et al. 2013). This activity is likely supported by the vertical flux of algae; flux rates of chlorophyll $a$ in March were consistent with inventories of chlorophyll $a$ extracted from surface sediments, which showed accumulations of up to $20 \mathrm{mg} \mathrm{m}^{-2}$ (Cooper et al. 2013). The large amount of chlorophyll $a$ in the surface sediments supports my observations that the majority of material sinking from the ice was in the form of "fresh" algal cells. In general, primary production is modified during its export from surface to benthos, and vertical flux can be composed of ungrazed algae, organic debris (e.g., empty frustules, detritus), and fecal pellets from zooplankton (e.g., Fortier et al. 1994). The contribution of fecal pellets can be up to $99 \%$ of the overall marine flux depending on season and region (Lampitt et al. 1990), but under the ice in this study they appeared only rarely. Empty diatom frustules contributed less than $20 \%$ to the overall flux of cells during ice growth, and only $3 \%$ during ice melt. Thus the majority of algal production sinking from the ice goes directly to the benthos without being reworked through the pelagic system, making it a high quality food source. 
In order to make comprehensive regional comparisons of vertical flux rates, I included chlorophyll measurements from ice, water and sediment traps conducted within the BEST program (R. Gradinger, unpublished data). The vertical pigment flux averaged $1.10 \mathrm{mg}$ chlorophyll $a \mathrm{~m}^{-2}$ day $^{-1}$ during ice growth and $3.08 \mathrm{mg}$ chlorophyll $a \mathrm{~m}^{-2}$ day $^{-1}$ during ice melt (Table 2; R. Gradinger, unpublished data); pigment fluxes were significantly positively related to the presented flux of algal cells in this study $(r=0.66, p<0.05)$.

In comparison to other subarctic and Arctic seas, the flux rate of chlorophyll $a$ in the Bering Sea was of a comparable order of magnitude for early spring (e.g., Michel et al. 1997, Olli et al. 2002, Lalande et al. 2014). While vertical flux patterns vary across the Arctic, there is consistently a large peak during ice melt and break-up, with flux rates rising by several orders of magnitude from early to late spring (e.g. Bauerfeind 1994; Lalande et al. 2009, Lalande et al. 2014). As the highest flux in the Bering Sea was measured on the latest date sampled (May 2, 2009) when ice cover was still $75 \%$, it is likely that the vertical flux rate continued to increase later in the spring as ice melt progressed. The dynamics of vertical flux from sea ice are not yet well understood, as they are controlled by both physical (e.g., temperature, ice ablation, water column stratification; Thomas and Dieckmann 2003) and biological factors (e.g., zooplankton grazing, algal physiology as it affects sinking rate; Smayda 1970; Peinert et al. 2001), and these drivers vary both regionally and seasonally (Peinert et al. 2001).

The proxy used to quantify algae also has an effect on the measured flux rate. Measuring the chlorophyll $a$ concentration is often chosen for its simple, efficient and objective technique; however, it is only a rough proxy for the actual quantity of algae. The amount of chlorophyll $a$ in a cell varies depending on health, growth status, and adaptations to light conditions (Thomas and Dieckmann 2003), so the carbon to chlorophyll $a$ ratio can vary tremendously in different regions and at different times of the year. Calculations of chlorophyll $a$ per cell in this study were very high in the sediment trap samples, likely due to the photoacclimation of the algae (Table 2), so using pigment data alone could overestimate algal biomass. Furthermore, chlorophyll $a$ concentrations fail to include empty frustules, which can provide information about the overall quality of the food that is exported. Other estimates of biogenic flux rates use particulate organic carbon (e.g., Moran et al. 2005; Fahl and Nöthig 2007), which, although useful, is not exclusive to algae and contains other carbon sources including zooplankton, heterotrophic bacteria, and 
detritus. Measurements of biogenic silicate can be used specifically to estimate the contribution of diatoms, radiolarians and silicoflagellates (e.g., Wefer and Fischer 1991; Fahl and Nöthig 2007), but these measurements do not provide information about community composition. It is only by using cell counts that algal cells can be directly enumerated and these numbers compared across space and time. While counting cells is slower, more subjective, and can be biased towards large and well-preserved organisms, it is the only method that allows us to assess the relative contribution of different species, which is essential for comparing the community composition in different domains and addressing species-specific questions about algal fate.

\section{Fate of ice algae}

During the period of ice growth, the high vertical flux rate and low phytoplankton standing stock indicated the release of ice algae into the water, which is supported by the strong similarity in the species inventory in ice and traps. However, the relative species composition for ice and water was different during this period and there was no correlation between the two sample sets (Fig. 5A). One explanation for such differences can be episodic release of ice algal cells into the water; the phytoplankton is seeded with ice algae, followed by the selection of ice species that are best adapted to growth in the water column resulting in similar species inventories but different and uncorrelated proportions of each species in the ice and the water. The significantly higher proportion of centric diatoms in the water compared with the ice supports this theory, as centric taxa typically dominant in the summer phytoplankton in the Bering Sea, although they play a minor role among the ice algae. Furthermore, there were significantly lower proportions of Nitzschia frigida in the water than in the ice; as a classically ice-associated species, $N$. frigida is rarely found anywhere among the phytoplankton, in agreement with its diminished proportion there observed in this study. The same relative species composition in the water and the traps during the ice growth period suggests that a large portion

of the algal cells in the water column - either phytoplankton or released ice algae — sank directly to the benthos, independent of ice-water species differences.

During the period of ice melt, the relative species composition in the ice and the water were the same and were significantly correlated, showing a stronger and more consistent 
connection between the ice and the water than during the ice growth period (Fig. 5B). This merging of ice and water domains is characteristic of ice melt in seasonally ice-covered regions, marked by high vertical flux rates and the presence of ice algal species in the water column as the ice ceases to exist as a habitat and its contents are deposited into the water (Leu et al. 2014).

The fate of the ice algal community during ice melt varies across the Arctic: cells can sink to the benthos, be grazed in the water column, or remain viable and contribute to the phytoplankton by seeding the spring bloom (Legendre et al. 1981; Riebesell et al. 1991; Durbin and Casas 2014). Algae will preferentially sink if cells are unhealthy or prone to forming aggregates, increasing their sinking rate; high abundances of zooplankton can deflect a significant flux of cells into the pelagic food web, reducing the amount exported to the benthos. Favorable environmental conditions (i.e., sufficient light and water column stratification) coupled with healthy ice algal cells and low grazing will allow for the growth of ice algae among the phytoplankton. In the Bering Sea, I found no evidence for the formation of aggregates that would increase the export of ice algae beneath the ice. The rapid export of the Arctic sea ice diatom Melosira arctica, which can account for up to $85 \%$ of the total carbon export under the ice (Boetius et al. 2013), was not detected in this study as M. arctica only rarely occurred in the ice in the Bering Sea and was completely absent from the trap samples. The species composition of algae exported beneath the ice in the Bering Sea was significantly different from the species composition in the ice during the period of ice melt, with higher proportions of Nitzschia frigida in the ice and higher proportions of species forming ribbon-colonies in the traps, indicating that ice algal fate differs among species. These changes to the algal composition could have been caused by a number of different factors, discussed below.

One possible factor influencing algal composition is grazing pressure. Although zooplankton grazing in the Bering Sea is typically low in the cold water during early spring (Coyle and Cooney 1988), molecular analysis of gut contents show that even during cold years Calanus glacialis grazes on ice algae during the early spring, and the pulses of algae released from the ice prior to ice melt "jump start" C. glacialis' feeding and reproduction (Durbin and Casas 2014). Therefore, zooplankton grazing could have played a role in altering ice algal fate. The lack of corresponding fecal pellets in the trap samples could be a function of the high assimilation efficiency of Arctic copepods, which can be up to 90\% (Conover and Huntley 
1991); loss of fecal pellets through coprophagy or coprorhexy could also account for their low numbers (Iversen and Poulsen 2007). It may also have been due to the timing of the trap deployments, which only occurred during daytime hours, and therefore may have missed the flux of fecal pellets from zooplankton grazing during diel vertical migration. Significant grazing has been documented for microzooplankton both before and during the spring phytoplankton bloom in the Bering Sea (Sherr et al. 2013). While these herbivorous protists consume a much larger range of phytoplankton size classes than traditionally believed (Sherr et al. 2013), ice algal and phytoplankton species that form large chains (i.e., Fragilariopsis spp.) may still escape this grazing pressure, resulting in preferential grazing of the smaller solitary cells. This could explain the larger proportion of chain-forming species in the traps relative to the ice.

Differential sinking rates could also alter the relative species composition between the ice and the traps. The sinking rate of a cell depends on its size, shape and physiology as well as its tendency for aggregation. On average, the sinking rate of a solitary diatom is $\sim 0.50 \mathrm{~m} \mathrm{day}^{-1}$ (Eppley et al. 1967); however, chains of cells can sink much faster: in some cases, a 10-cell increase in colony length can as much as quadruple the sinking rate (Smayda 1971). Long colonies of Fragilariopsis spp. and Fossula arctica, which were often over 50 cells in length, likely sank at a rapid rate, resulting in their high proportions in the sediment traps. It is important to note that not only did different sinking rates influence the rate at which different species were collected in the traps, but they also dictated how large the temporal disconnect was between the ice and the trap samples. For example, small solitary cells may have taken up to two weeks to reach the traps at $5 \mathrm{~m}$ depth, during which time the community in the ice may have shifted, while large colonies could have been representatives of the ice algal community only days before.

Although lateral advection and resuspension from sediment could have caused differences in the relative species composition between ice and traps, similar differences in algal composition in the ice and traps as found in this study have been observed elsewhere. In Baffin Bay, Michel et al. (2002) saw the same pattern in the relative species composition with higher proportions of $N$. frigida in the ice and higher proportions of Fragilariopsis spp. in the traps, suggesting that the differences may be specific to taxa rather than location. $N$. frigida may dissociate from its characteristic branching colonies when it senesces in the water column, and thus be counted among the unknown pennate diatoms, resulting in underestimates in sediment 
trap samples. Fragilariopsis spp. have a very low specific dissolution rate due to the structure and composition of its frustule (Passow et al. 2011), which could result in its accumulation in the traps. In Antarctic waters, comparisons of species between ice and sediment traps suggest that lightly silicified frustules are rapidly recycled in the water column (Leventer and Dunbar 1987); however, there is no evidence for silicate dissolution in the subarctic Pacific even over much greater depths (Takahashi 1986), and it is unlikely to have been an issue in this study doe to the shallow depth of the traps.

Although I did not capture the start of the spring phytoplankton bloom during the sampling years, and my data show the propensity for algal cells to sink in large quantities during the spring, ice algal fate likely changes as ice melt progresses. Virtually all ice algal species in the Bering Sea are capable of growing in the water column, and although it is difficult to assess viability in fixed cells, the majority of cells in the water showed no degradation in their chloroplast structure and the cells appeared to be healthy. These cells may have been highly lowlight adapted; using cell counts from this study and chlorophyll $a$ concentrations from the same stations, I estimated that the average chlorophyll content in the sub-ice phytoplankton was $24 \mathrm{pg}$ cell $^{-1}$, higher than for typical phytoplankton cells (1-12 pg chl $a$ cell $^{-1}$; Sosik et al. 1989) and over three times higher than the estimate of chlorophyll $a$ content of cells in the overlying ice (on average $7 \mathrm{pg} \mathrm{cell}^{-1}$ ). While it is possible that this is an overestimation due to the exclusion of small cells in my counts, chlorophyll $a$ contents of this magnitude have been found in highly photoacclimated ice algal cells under similar light conditions (Gosselin et al. 1990). Although phytoplankton growth rates under the ice in the Bering Sea were low $\left(<0.1 \mathrm{~d}^{-1}\right)$, they increased significantly as soon as bloom conditions developed (Sherr et al. 2013). This suggests that although extensive ice cover held off the development of the phytoplankton bloom at least into early May, when the ice ultimately retreated, the water was primed for the spring ice-edge bloom with viable ice algal species.

Additional evidence supports ice algal seeding in the Bering Sea. Model forecasts of primary production in the southeastern Bering Sea are more predictive when ice algal seeding is incorporated in the ice-edge bloom (Jin et al. 2007). The timing of the spring bloom matches that of the receding ice in the Bering Sea (Alexander and Chapman 1981), unlike some regions where there is a large temporal disconnect (Horner and Schrader 1982, and references therein). The 
results of this study in addition to those findings suggest that ice algae do seed the spring phytoplankton bloom in the Bering Sea, as is common in many other subarctic and Arctic seas (e.g., Legendre et al. 1981; Michel et al. 1993; Haecky et al. 1998).

According to the Oscillating Control Hypothesis (Hunt and Stabeno 2002), ice algae could only seed the spring ice-edge bloom if the timing of ice melt is late enough that it coincides with sufficient irradiance for phytoplankton growth. In 2008 and 2009, this was extremely likely, as the ice was still in the early stages of melt in early May when the day length exceeded $16.50 \mathrm{hrs}$. However, if the ice melts early in the spring, as occurs during warm years, there is insufficient light for phytoplankton growth and the ice-edge bloom does not occur; instead, a later open-water bloom develops when solar heating rather than melt water stratifies the water column (Hunt and Stabeno 2002). Although there is no significant difference in the magnitude of spring blooms during warm versus cold years (Sigler et al. 2014), the timing of the bloom has tremendous implications for the fate of primary production. During cold years, as sampled in this study, there is a mismatch between the timing of the ice edge-bloom and the phenology of zooplankton development, so the bloom is primarily exported to the benthos, while in warm years the late development of the bloom coincides with that of zooplankton populations, which readily graze the available algae, diverting energy into the pelagic system (Sigler et al. 2014). Therefore, the seasonal ice extent has tremendous implications for the overall ecosystem of the Bering Sea.

Unlike most Arctic seas, where sea ice is declining rapidly, there has so far been no decrease in annual sea ice extent in the Bering Sea (Brown and Arrigo 2012). However, much of ice growth in the Bering Sea is driven by cold northerly Arctic air creating a "conveyor belt" of ice production in northern polynas and then advecting it south across the shelf (Pease 1980). As Arctic air temperatures are rising at twice the global rate (Pachauri and Reisinger 2007), northerly winds will continue to warm, which may ultimately have a large effect on the development of Bering Sea ice. This could result in a higher proportion of warm years in the Bering Sea with reduced ice extent and earlier ice retreat. Under these conditions, a larger portion of the ice algal production would be exported to the benthos during ice melt, but the ice algal contribution to seeding the phytoplankton would become negligible, and when the openwater bloom developed later in the summer, high zooplankton grazing would keep more of this 
production in the pelagic realm. Thus, the majority of the material exported to the benthos would more likely be in the form of fecal pellets rather than ungrazed algal cells.

Presumably, sufficient warming could result in the permanent loss of sea ice off the southern shelf, eliminating all input from ice algae, which could have noticeable effects on benthic communities. But even drastic climate change would be unlikely to have such an effect. Climate models show that a doubling atmospheric $\mathrm{CO}_{2}$ and increased temperatures by as much as $2^{\circ} \mathrm{C}$ would result only in an increase in warm-year conditions but nowhere near complete ice loss in the Bering Sea (Lee et al. 2012). Ice extent would be reduced by 300-400 km in southern latitudes of the Bering Sea but the mid-latitude shelf would remain ice covered through March, much like during warm years today. The Bering Sea's seasonal ice cover is likely to remain one of its most defining characteristics even in the face of a warming climate.

\section{Conclusions}

I present here the results of the first quantitative assessment of Bering Sea ice algal communities, which have a community composition similar to many of those in other Arctic regions. Ice algal abundance was high in the Bering Sea throughout the spring, and continued to increase during the late spring period of ice melt. The growth of ice algae during the spring is essential for grazers as phytoplankton abundance beneath the ice remained very low during these cold years, with no increase in magnitude even as late as May $1^{\text {st }}$. The phytoplankton present during the spring were seeded from the ice; phytoplankton communities appeared to be influenced first by the episodic input from the ice algal community during the period of ice growth and then by the more regular release of cells from the ice during the period of ice melt. Due to the cold conditions in the Bering Sea during this study, I did not observe the development of the spring phytoplankton bloom from March-May; however, these results show that the existing phytoplankton community prior to the ice retreat was comprised of healthy ice algal cells that would be in place to seed the ice-edge bloom.

I further found that there was a substantial vertical flux of algal cells beneath the ice, which began as early as mid-March, suggesting that the export of sympagic primary production 
to the benthos may be greater than previously predicted and is not restricted to the period of ice melt. Due to the relatively low zooplankton grazing pressures in the cold water, the vast majority of primary production is exported in the form of "fresh" algal cells rather than fecal pellets, and it is, therefore, a rich source of food for benthic organisms long before the ice melts.

My study characterizes the dynamics of ice algal and phytoplankton communities during two cold springs in the Bering Sea. Although it is restricted to only a two month period, it can be used as a baseline for interactions between ice algae and phytoplankton and the underlying benthos under ice-covered spring conditions. These interactions will differ substantially as conditions change during warm years in the Bering Sea, which may become more prevalent in the future, increasing our need to understand the connection between sympagic, pelagic and benthic communities in the Bering Sea. 


\section{References}

Alexander V, Chapman T (1981) The role of epontic algal communities in Bering Sea ice. In: Hood D, Calder J (eds) Eastern Bering Sea Shelf: Oceanography and Resources. NOAA, Seattle, pp 773-780

Ambrose WG, von Quillfeldt C, Clough LM, et al. (2005) The sub-ice algal community in the Chukchi Sea: large- and small-scale patterns of abundance based on images from a remotely operated vehicle. Polar Biol 28:784-795

Anderson M (2001) A new method for non-parametric multivariate analysis of variance. Austral Ecol 26:32-46

Arrigo KR, Perovich DK, Pickart RS, et al. (2012) Massive phytoplankton blooms under Arctic sea ice. Science 336:1408

Arrigo KR, Perovich DK, Pickart RS, et al. (2014) Phytoplankton blooms beneath the sea ice in the Chukchi Sea. Deep Sea Res II 105:1-16

Bauerfeind E (1994) Particle flux and composition of sedimenting matter in the Greenland Sea. J Mar Syst 5:411-423

Bluhm B, Gradinger R (2008) Regional variability in food availability for Arctic marine mammals. Ecol Appl 18:S77-S96

Boetius A, Albrecht S, Bakker K, et al. (2013) Export of algal biomass from the melting Arctic sea ice. Science 339:1430-1432

Booth JA (1984) The epontic algal community of the ice edge zone and its significance to the Davis Strait ecosystem. Arctic 37:234-243

Booth B, Horner R (1997) Microalgae on the Arctic Ocean Section, 1994: species abundance and biomass. Deep Sea Res II 44:1607-1622

Brown Z, Arrigo K (2012) Contrasting trends in sea ice and primary production in the Bering Sea and Arctic Ocean. J Mar Sci 69:1180-1193

Carr J, Hergenrader G, Troelstrup NH (1986) A simple, inexpensive method for cleaning diatoms. Trans Am Microsc Soc 105:152-157

Clarke K (1993) Non-parametric multivariate analyses of changes in community structure. Aust J Ecol 18:117-143 
Colwell R (2000) EstimateS: Statistical estimation of species richness and shared species from samples (Software and User's Guide), version 9.1

Conover R, Huntley M (1991) Copepods in ice-covered seas-distribution, adaptations to seasonally limited food, metabolism, growth patterns and life cycle strategies in polar seas. J Mar Syst 2:1-41

Cooper LW, Sexson MG, Grebmeier JM, et al. (2013) Linkages between sea-ice coverage, pelagic-benthic coupling, and the distribution of spectacled eiders: observations in March 2008, 2009 and 2010, northern Bering Sea. Deep Sea Res II 94:31-43

Coyle KO, Cooney R (1988) Estimating carbon flux to pelagic grazers in the ice-edge zone of the eastern Bering Sea. Mar Biol 98:299-306

Druzhkov N, Druzhkova E, Kuznetsov L (2001) The sea-ice algal community of seasonal pack ice in the southwestern Kara Sea in late winter. Polar Biol 24:70-72

Durbin EG, Casas MC (2014) Early reproduction by Calanus glacialis in the northern Bering Sea: the role of ice algae as revealed by molecular analysis. J Plankton Res 36:523-541

Edler L, Elbrächter M (2010) The Utermöhl method for quantitative phytoplankton analysis. Karlson B, Cusack C, Bresnan E (eds) Microscopic and Molecular Methods for Quantitative Phytoplankton Analysis. UNESCO, Paris, pp 13-20

Eicken H, Gradinger R, Salganek M, Shirasawa K, Perovich D, Lepparanta M (2009) Field Techniques for Sea-Ice Research. University of Alaska Press, Fairbanks, 592 pp

Eppley R, Holmes R, Strickland J (1967) Sinking rates of marine phytoplankton measured with a fluorometer. J Exp Mar Biol Ecol 1:191-208

Fahl K, Nöthig EM (2007) Lithogenic and biogenic particle fluxes on the Lomonosov Ridge (central Arctic Ocean) and their relevance for sediment accumulation: vertical vs. lateral transport. Deep Sea Res I 54:1256-1272

Falk-Petersen S, Sargent J (1998) Lipids and fatty acids in ice algae and phytoplankton from the Marginal Ice Zone in the Barents Sea. Polar Biol 20:41-47

Fortier L, Le Fèvre J, Legendre L (1994) Export of biogenic carbon to fish and to the deep ocean: the role of large planktonic microphages. J Plankton Res 16:809-839

Fortier M, Fortier L, Michel C, Legendre L (2002) Climatic and biological forcing of the vertical flux of biogenic particles under seasonal Arctic sea ice. Mar Ecol Prog Ser 225:1-16 
Garrison D, Buck K (1986) Organism losses during ice melting: a serious bias in sea ice community studies. Polar Biol 6:237-239

Gosselin M, Legendre L, Therriault J, et al. (1990) Light and nutrient limitation of sea-ice microalgae (Hudson Bay, Canadian Arctic). J Phycol 26:220-232

Gosselin M, Levasseur M (1997) New measurements of phytoplankton and ice algal production in the Arctic Ocean. Deep Sea Res II 44:1623-1644

Gradinger R (1996) Occurrence of an algal bloom under Arctic pack ice. Mar Ecol Prog Ser 131:301-305

Gradinger R (2009) Sea-ice algae: major contributors to primary production and algal biomass in the Chukchi and Beaufort Seas during May/June 2002. Deep Sea Res II 56:1201-1212

Grebmeier J (1988) Pelagic-benthic coupling on the shelf of the northern Bering and Chukchi seas. I. Food supply source and benthic biomass. Mar Ecol Prog Ser 48:57-67

Haecky P, Jonsson S, Andersson A (1998) Influence of sea ice on the composition of the spring phytoplankton bloom in the northern Baltic Sea. Polar Biol 20:1-8

Hasle GR, Fryxell GA (1970) Diatoms: cleaning and mounting for light and electron microscopy. Trans Am Microsc Soc 89:469-474

Hegseth EN (1998) Primary production of the northern Barents Sea. Polar Res 17:113-123

Horner R (1985) Sea Ice Biota. CRC Press, Boca Raton, 224 pp

Horner R, Schrader G (1982) Relative contributions of ice algae, phytoplankton, and benthic microalgae to primary production in nearshore regions of the Beaufort Sea. Arctic 35:485503

Hsiao SC (1980) Quantitative composition, distribution, community structure and standing stock of sea ice microalgae in the Canadian Arctic. Arctic 33:768-793

Hsiao SC (1983) A checklist of marine phytoplankton and sea ice microalgae recorded from Arctic Canada. Nov Hedwig 37:225-313

Hsiao SC (1992) Dynamics of ice algae and phytoplankton in Frobisher Bay. Polar Biol 12:645651

Hunt GL, Stabeno PJ (2002) Climate change and the control of energy flow in the southeastern Bering Sea. Prog Oceanogr 55:5-22 
Hunt GL, Stabeno PJ, Strom S, et al. (2008) Patterns of spatial and temporal variation in the marine ecosystem of the southeastern Bering Sea, with special reference to the Pribilof Domain. Deep Sea Res II 55:1919-1944

Ikavalko J, Thomsen H (1997) The Baltic Sea ice biota (March 1994): a study of the protistan community. Eur J Protistol 33:229-243

Ikavalko J, Gradinger R (1998) Organism incorporation into newly forming Arctic sea ice in the Greenland Sea. J Plankton Res 20:871-886

Iken K, Bluhm B, Gradinger R (2005) Food web structure in the high Arctic Canada Basin: evidence from $\delta^{13} \mathrm{C}$ and $\delta^{15} \mathrm{~N}$ analysis. Polar Biol 28:238-249

Iversen M, Poulsen LK (2007) Coprohexy, coprophagy, and coprochaly in the copepods Calanus helgolandicus, Pseudocalanus elongatus, and Oithona similis. Mar Ecol Prog Ser 350:79-89

Jin M, Deal C, Wang J, et al. (2007) Ice-associated phytoplankton blooms in the southeastern Bering Sea. Geophys Res Lett 34:L06612

Lalande C, Forest A, Barber DG, et al. (2009) Variability in the annual cycle of vertical particulate organic carbon export on Arctic shelves: contrasting the Laptev Sea, Northern Baffin Bay and the Beaufort Sea. Cont Shelf Res 29:2157-2165

Lalande C, Nöthig EM, Somavilla R, et al. (2014) Variability in under-ice export fluxes of biogenic matter in the Arctic Ocean. Global Biogeochem Cyc 28:571-583

Lampitt R, Noji T, von Budungen B (1990) What happens to zooplankton faecal pellets? Implications for material flux. Mar Biol 104:15-23

Lebour M (1930) The Planktonic Diatoms of Northern Seas. Ray Society, London, 244 pp

Lee HC, Delworth TL, Rosati A, et al. (2012) Impact of climate warming on upper layer of the Bering Sea. Clim Dyn 40:327-340

Legendre L, Ingram R, Poulin M (1981) Physical control of phytoplankton production under sea ice. Can J Fish Aquat Sci 38:1385-1392

Legendre L, Aota M, Shirasawa K, et al. (1991) Crystallographic structure of sea ice along a salinity gradient and environmental control of microalgae in the brine cells. J Mar Syst $2: 347-357$

Leu E, Wiktor J, Søreide J, et al. (2010) Increased irradiance reduces food quality of sea ice algae. Mar Ecol Prog Ser 411:49-60 
Leu E, Søreide JE, Hessen DO, et al. (2011) Consequences of changing sea-ice cover for primary and secondary producers in the European Arctic shelf seas: timing, quantity, and quality. Prog Oceanogr 90:18-32

Leu E, Mundy CJ, Assmy P, et al. (2014) Arctic spring awakening - steering principles behind the phenology of vernal ice algae blooms. Manuscript in review at Progress in Oceanography.

Leventer A, Dunbar RB (1987) Diatom flux in McMurdo Sound, Antarctica. Mar Micropaleo 12:49-64

Loughlin T, Ohtani K (1999) Dynamics of the Bering Sea: A Summary of Physical, Chemical, and Biological Characteristics and a Synopsis of Research on the Bering Sea. University of Alaska Sea Grant, Fairbanks, 838 pp

Lovejoy C, Legendre L, Martineau MJ, et al. (2002) Distribution of phytoplankton and other protists in the North Water. Deep Sea Res II 49:5027-5047

Mantel N (1967) The detection of disease clustering and a generalized regression approach. Cancer Res 27:209-220

Margalef R (1977) Ecosystem diversity differences: poles and tropics. In: Dunbar MJ (ed) Polar Oceans. Arctic Institute of North America, Calgary, pp 367-375

McMinn A, Hegseth E (2004) Quantum yield and photosynthetic parameters of marine microalgae from the southern Arctic Ocean, Svalbard. J Mar Biol Ass UK 84:865-871

McMinn A, Hattori H, Hirawake T, et al. (2008) Preliminary investigation of Okhotsk Sea ice algae; taxonomic composition and photosynthetic activity. Polar Biol 31:1011-1015

McRoy C, Goering J (1974) The influence of ice on the primary productivity of the Bering Sea. In: Hood D, Kelley E (eds) Oceanography of the Bering Sea, vol 2. pp 403-421

Melnikov I (1987) The Arctic Sea Ice Ecosystem. Gordon and Breach Science Publishers, Amsterdam, $221 \mathrm{pp}$

Melnikov I, Kolosova EG, Welch HE, et al. (2002) Sea ice biological communities and nutrient dynamics in the Canada Basin of the Arctic Ocean. Deep Sea Res I 49:1623-1649

Michel C, Legendre L (1996) Carbon budget of sea-ice algae in spring: evidence of a significant transfer to zooplankton grazers. J Geophys Res 101:345-360 
Michel C, Legendre L, Therriault JC, et al. (1993) Springtime coupling between ice algal and phytoplankton assemblages in southeastern Hudson Bay, Canadian Arctic. Polar Biol 13:441-449

Michel C, Legendre L, Taguchi S (1997) Coexistence of microalgal sedimentation and water column recylcing in a seasonally ice-covered ecosystem. J Mar Syst 11:133-148

Michel C, Nielsen TG, Nozais C, et al. (2002) Significance of sedimentation and grazing by ice micro- and meiofauna for carbon cycling in annual sea ice (northern Baffin Bay). Aquat Microb Ecol 30:57-68

Michel C, Ingram RG, Harris LR (2006) Variability in oceanographic and ecological processes in the Canadian Arctic Archipelago. Prog Oceanogr 71:379-401

Mock T, Gradinger R (1999) Determination of Arctic ice algal production with a new in situ incubation technique. Mar Ecol Prog Ser 177:15-26

Moran SB, Kelly RP, Hagstrom K, et al. (2005) Seasonal changes in POC export flux in the Chukchi Sea and implications for water column-benthic coupling in Arctic shelves. Deep Sea Res II 52:3427-3451

Moran SB, Lomas MW, Kelly RP, et al. (2012) Seasonal succession of net primary productivity, particulate organic carbon export, and autotrophic community composition in the eastern Bering Sea. Deep Sea Res II 70:84-97

Okolodkov Y (1993) A checklist of algal species found in the East Siberian Sea in May 1987. Polar Biol 13:7-11

Olli K, Wexels Riser C, Wassmann P, et al. (2002) Seasonal variation in vertical flux of biogenic matter in the Marginal Ice Zone and the central Barents Sea. J Mar Syst 38:189-204

Overland J, Stabeno P, Wang M, et al. (2009) Eastern Bering Sea climate. PMEL/NOAA, http://access.afsc.noaa.gov/reem/ecoweb/content/pdf/TempAndIceBS.pdf

Pachauri RK, Reisinger A (2007) Contribution of Working Groups I, II and III to the Fourth Assessment Report of the Intergovernmental Panel on Climate Change. IPCC, Geneva, 104 $\mathrm{pp}$

Passow U, French M, Robert M (2011) Biological controls on dissolution of diatom frustules during their descent to the deep ocean: lessons learned from controlled laboratory experiments. Deep Sea Res I 58:1147-1157

Pease C (1980) Eastern Bering Sea ice processes. Mon Weather Rev 1:2015-2023 
Peinert R, Antia A, Bauerfeind E, et al. (2001) Particle flux variability in the Polar and Atlantic biogeochemical provinces of the Nordic Seas. In: The Northern North Atlantic. Springer, Berlin, pp 53-68

Petrich C, Nicolaus M, Gradinger R (2012) Sensitivity of the light field under sea ice to spatially inhomogeneous optical properties and incident light assessed with three-dimensional Monte Carlo radiative transfer simulations. Cold Reg Sci Technol 73:1-11

Pogson L, Tremblay B, Lavoie D, et al. (2011) Development and validation of a one-dimensional snow-ice algae model against observations in Resolute Passage, Canadian Arctic Archipelago. J Geophys Res 116:C04010

Poulin M, Daugbjerg N, Gradinger R, et al. (2011) The pan-Arctic biodiversity of marine pelagic and sea-ice unicellular eukaryotes: a first-attempt assessment. Mar Biodivers 41:13-28

Poulin M, Underwood G, Michel C (2014) Sub-ice colonial Melosira arctica in Arctic first-year ice. Diatom Res 29:213-221

Reimnitz E (1992) Suspension freezing of bottom sediment and biota in the Northwest Passage and implications for Arctic Ocean sedimentation. Can J Earth Sci 29:693-703

Reimnitz E, Clayton J (1993) Interaction of rising frazil with suspended particles: tank experiments with applications to nature. Cold Reg Sci 21:117-135

Riebesell U, Schloss I, Smetacek V (1991) Aggregation of algae released from melting sea ice: implications for seeding and sedimentation. Polar Biol 11:239-248

Riedel A, Michel C, Gosselin M, LeBlanc B (2007) Enrichment of nutrients, exopolymeric substances and microorganisms in newly formed sea ice on the Mackenzie shelf. Mar Ecol Prog Ser 342:55-67

Sanders H (1968) Marine benthic diversity: a comparative study. Am Nat 102:243-282

Schandelmeier L, Alexander V (1979) A quantitative study of the phytoplankton from the eastern Bering Sea. In: Alexander V (ed) Ice Edge Ecosystem Study: Final Report to National Oceanographic and Atmospheric Association, Shelf Environment Assessment Program. University of Alaska, Institute of Marine Science, Fairbanks, 153 pp

Schandelmeier L, Alexander V (1981) An analysis of the influence of ice on spring phytoplankton population structure in the southeast Bering Sea. Limnol Oceanogr 26:935943

Sherr EB, Sherr BF, Ross C (2013) Microzooplankton grazing impact in the Bering Sea during spring sea ice conditions. Deep Sea Res II 94:57-67 
Sigler M, Harvey H (2010) How does climate change affect the Bering Sea ecosystem? Eos 91:457-468

Sigler MF, Stabeno PJ, Eisner LB, et al. (2014) Spring and fall phytoplankton blooms in the Eastern Bering Sea during 1995 - 2011. Alaska Fish Sci Center, Quarterly Report 1-6 http://www.afsc.noaa.gov/Quarterly/AMJ2014/AMJ2014.pdf

Smayda T (1970) The suspension and sinking of phytoplankton in the sea. Oceanogr Mar Biol Annu Rev 8:353-414

Smayda T (1971) Normal and accelerated sinking of phytoplankton in the sea. Mar Geol 11:105122

Sosik H, Chisholm S, Olson R (1989) Chlorophyll fluorescence from single cells: interpretation of flow cytometric signals. Limnol Ocean 34:1749-1761

Stabeno P, Napp J, Mordy C, et al. (2010) Factors influencing physical structure and lower trophic levels of the eastern Bering Sea shelf in 2005: sea ice, tides and winds. Prog Oceanogr 85:180-196

Stabeno PJ, Farley EV, Kachel NB, et al. (2012a) A comparison of the physics of the northern and southern shelves of the eastern Bering Sea and some implications for the ecosystem. Deep Sea Res II 70:14-30

Stabeno PJ, Kachel NB, Moore SE, et al. (2012b) Comparison of warm and cold years on the southeastern Bering Sea shelf and some implications for the ecosystem. Deep Sea Res II $70: 31-45$

Takahashi K (1986) Seasonal fluxes of pelagic diatoms in the subarctic Pacific, 1982-1983. Deep Sea Res II 33:1225-1251

Tamelander T, Heiskanen AS (2004) Effects of spring bloom phytoplankton dynamics and hydrography on the composition of settling material in the coastal northern Baltic Sea. J Mar Syst 52:217-234

Taniguchi A, Saito K, Koyama A, et al. (1976) Phytoplankton communities in the Bering Sea and adjacent seas. J Oceanogr Soc Japan 32:99-106

Tett P, Barton ED (1995) Why are there about 5000 species of phytoplankton in the sea? J Plank Res 17:1693-1704

Thomas D, Dieckmann G (2003) Sea Ice, $2^{\text {nd }}$ ed. Wiley and Blackwell, Hoboken, 640 pp

Tomas C (1997) Identifying Marine Phytoplankton. Academic Press, San Diego, 598 pp 
Tourangeau S, Runge J (1991) Reproduction of Calanus glacialis under ice in spring in southeastern Hudson Bay, Canada. Mar Biol 108:227-233

Tremblay JÉ, Hattori H, Michel C, et al. (2006) Trophic structure and pathways of biogenic carbon flow in the eastern North Water Polynya. Prog Oceanogr 71:402-425

Tuschling K, Juterzentka K, Okolodkov Y, Anoshkin A (2000) Composition and distribution of the pelagic and sympagic algal assemblages in the Laptev Sea during autumnal freeze-up. J Plankton Res 22:843-864

von Quillfeldt CH (2000) Common diatom species in Arctic spring blooms: their distribution and abundance. Bot Mar 43:499-516

von Quillfeldt CH (2004) The diatom Fragilariopsis cylindrus and its potential as an indicator species for cold water rather than for sea ice. Vie Milieu 54:137-143

von Quillfeldt CH, Ambrose WG, Clough LM (2003) High number of diatom species in firstyear ice from the Chukchi Sea. Polar Biol 26:806-818

Wang M, Bond N, Overland JE (2007) Comparison of atmospheric forcing in four sub-arctic seas. Deep Sea Res II 54:2543-2559

Wang SW, Budge SM, Gradinger RR, et al. (2014) Fatty acid and stable isotope characteristics of sea ice and pelagic particulate organic matter in the Bering Sea: tools for estimating sea ice algal contribution to Arctic food web production. Oecologia 174: 699-712

Wefer G, Fischer G (1991) Annual primary production and export flux in the Southern Ocean from sediment trap data. Mar Chem 35:597-613

Wendler G, Chen L, Moore B (2013) Recent sea ice increase and temperature decrease in the Bering Sea area, Alaska. Theor Appl Climatol 117:393-398

Zeebe RE, Eicken H, Robinson DH, et al. (1996) Modeling the heating and melting of sea ice through light absorption by microalgae. J Geophys Res 101:1163-1181 


\section{Appendix}

Table A-1. Station MN4 (169.655' W, 59.9 N). Sampled April 4, 2008 during the ice growth period.

\begin{tabular}{|c|c|c|c|}
\hline Species & $\begin{array}{l}\text { Ice algal } \\
\text { abundance } \\
\left(\text { cells } 1^{-1}\right)\end{array}$ & $\begin{array}{l}\text { Phytoplankton } \\
\text { abundance } \\
(\text { cells l-1) }\end{array}$ & $\begin{array}{c}\text { Flux rate } \\
\left(\begin{array}{c}\text { cells m } \\
\text { (ay }\end{array}\right. \\
\left.\text { day }^{-1}\right)\end{array}$ \\
\hline Biddulphia sp & 0 & 0 & 138060 \\
\hline Ceratoneis closterium & 16800 & 0 & 138060 \\
\hline Cocconeis sp. 1 & 0 & 120 & 276120 \\
\hline Coscinodiscus spp. & 0 & 20 & 0 \\
\hline Entomoneis sp. 1 & 0 & 0 & 69030 \\
\hline Entomoneis sp. 2 & 16800 & 0 & 0 \\
\hline Fossula arctica & 13200 & 0 & 0 \\
\hline Fragilariopsis spp. & 556800 & 1580 & 31201591 \\
\hline Gyrosigma sp. 1 & 9600 & 80 & 0 \\
\hline Navicula directa & 30000 & 60 & 345150 \\
\hline Navicula granii & 0 & 0 & 69030 \\
\hline Navicula kariana var. detersa & 88800 & 0 & 207090 \\
\hline Navicula septentrionalis & 36000 & 0 & 2277992 \\
\hline Navicula trigonocephala var. depressa & 10800 & 0 & 0 \\
\hline Navicula valida & 27600 & 0 & 0 \\
\hline Navicula vanhoeffenii & 21600 & 0 & 0 \\
\hline Nitzschia pellucida & 0 & 0 & 483210 \\
\hline Nitzschia frigida & 1038000 & 0 & 17602668 \\
\hline Nitzschia seriata & 0 & 0 & 138060 \\
\hline Nitzschia sp. 1 & 30000 & 0 & 621271 \\
\hline Paralia sulcata & 0 & 640 & 12080262 \\
\hline Pauliella taeniata & 0 & 0 & 276120 \\
\hline Pinnularia quadratarea var. constricta & 0 & 0 & 207090 \\
\hline Pinnularia sp. 1 & 19200 & 0 & 0 \\
\hline Pleurosigma spp. & 6000 & 0 & 207090 \\
\hline Pleurosigma tenuiforme & 0 & 0 & 69030 \\
\hline Pseudogomphonema groenlandicum & 21600 & 0 & 69030 \\
\hline Pseudogomphonema septentrionale & 48000 & 0 & 0 \\
\hline Thalassionema nitzschioides & 0 & 40 & 138060 \\
\hline Thalassiosira spp. & 6000 & 60 & 207090 \\
\hline
\end{tabular}


Table A-1, continued

Unidentified pennate diatoms

$\begin{array}{rrr}849600 & 160 & 15255645 \\ 0 & 80 & 0 \\ 0 & 190 & 6143676 \\ 0 & 0 & 69030 \\ 0 & 20 & 69030 \\ 0 & 80 & 207090 \\ 2846400 & 3130 & 88565579 \\ 2846400 & 2940 & 82352872\end{array}$

Table A-2. Station MN8.5 (172.766 $\left.{ }^{\circ} \mathrm{W}, 59.924^{\circ} \mathrm{N}\right)$. Sampled April 6, 2008 during the ice growth period.

\begin{tabular}{lrrr} 
Species & $\begin{array}{c}\text { Ice algal } \\
\text { abundance } \\
\left(\text { cells l }^{-1}\right)\end{array}$ & $\begin{array}{c}\text { Phytoplankton } \\
\text { abundance } \\
\left(\text { cells l }^{-1}\right)\end{array}$ & $\begin{array}{r}\text { Flux rate } \\
\left(\text { cells m }^{-2}\right. \\
\left.\text { day }^{-1}\right)\end{array}$ \\
\hline Entomoneis sp. 1 & & & \\
Fragilariopsis spp. & 500000 & 0 & 0 \\
Gyrosigma sp. 1 & 19200000 & 0 & 0 \\
Navicula directa & 2200000 & 0 & 36343 \\
Navicula kariana var. detersa & 100000 & 20 & 0 \\
Navicula septentrionalis & 100000 & 0 & 0 \\
Navicula vanhoeffenii & 1050000 & 0 & 0 \\
Nitzschia frigida & 500000 & 0 & 0 \\
Pauliella taeniata & 6100000 & 80 & 0 \\
Pinnularia quadratarea var. constricta & 2150000 & 0 & 0 \\
Pseudogomphonema groenlandicum & 100000 & 0 & 0 \\
Pseudogomphonema septentrionale & 50000 & 0 & 0 \\
Thalassionema nitzschioides & 150000 & 0 & 0 \\
Unidentified pennate diatoms & 0 & 120 & 36343 \\
Empty pennate diatoms & 7300000 & 180 & 290745 \\
Total cells & 0 & 130 & 0 \\
Total cells (excluding empty) & 39500000 & 530 & 363432 \\
& 39500000 & 400 & 363432
\end{tabular}


Table A-3. Station DLN2 (173.695 ${ }^{\circ}$, $\left.63.266^{\circ} \mathrm{N}\right)$. Sampled March 19, 2009 during the ice growth period. No water samples available from this station.

\begin{tabular}{|c|c|c|c|}
\hline Species & $\begin{array}{l}\text { Ice algal } \\
\text { abundance } \\
\left(\text { cells } 1^{-1}\right)\end{array}$ & $\begin{array}{l}\text { Phytoplankton } \\
\text { abundance } \\
\left(\text { cells } 1^{-1}\right)\end{array}$ & 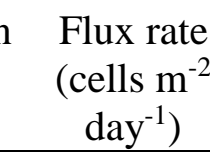 \\
\hline Ceratoneis closterium & 215021 & $\mathrm{n} / \mathrm{a}$ & 860093 \\
\hline Chaetoceros spp. & 109705 & & 0 \\
\hline Cocconeis sp. 1 & 0 & & 3440373 \\
\hline Entomoneis sp. 1 & 245738 & & 860093 \\
\hline Entomoneis sp. 2 & 0 & & 860093 \\
\hline Fossula arctica & 83376 & & 0 \\
\hline Fragilariopsis spp. & 2268692 & & 64506988 \\
\hline Navicula directa & 13165 & & 0 \\
\hline Navicula granii & 228186 & & 0 \\
\hline Nitzschia pellucida & 35105 & & 0 \\
\hline Nitzschia frigida & 245738 & & 0 \\
\hline Nitzschia seriata & 443207 & & 22362423 \\
\hline Nitzschia sigmoidea & 105316 & & 1720186 \\
\hline Nitzschia sp. 1 & 4388 & & 0 \\
\hline Nitzschia sp. 2 & 92152 & & 2580280 \\
\hline Pauliella taeniata & 0 & & 17201864 \\
\hline Pleurosigma spp. & 13165 & & 2580280 \\
\hline Pleurosigma tenuiforme & 0 & & 860093 \\
\hline Pseudogomphonema septentrionale & 4388 & & 0 \\
\hline Thalassiosira spp. & 21941 & & 9461025 \\
\hline Unidentified pennate diatoms & 535359 & & 6880745 \\
\hline Unidentified centric diatoms & 0 & & 5160559 \\
\hline Empty pennate diatoms & 160169 & & 12471351 \\
\hline Empty centric diatoms & 0 & & 5160559 \\
\hline Unidentified flagellates & 4388 & & 0 \\
\hline Total cells & 4829198 & & 156967005 \\
\hline Total cells (excluding empty) & 4669030 & & 139335095 \\
\hline
\end{tabular}


Table A-4. Station NWC1 (172.316 W, 63.485 N). Sampled March 17, 2009 during the ice growth period.

\begin{tabular}{|c|c|c|c|}
\hline Species & $\begin{array}{l}\text { Ice algal } \\
\text { abundance } \\
\left(\text { cells }^{-1}\right)\end{array}$ & $\begin{array}{l}\text { Phytoplankton } \\
\text { abundance } \\
\text { (cells } 1^{-1} \text { ) }\end{array}$ & $\begin{array}{l}\text { Flux rate } \\
\left(\text { cells }^{-2}\right. \\
\left.\text { day }^{-1}\right)\end{array}$ \\
\hline Ceratoneis closterium & 107829 & 60 & 404087 \\
\hline Chaetoceros spp. & 0 & 80 & 1558621 \\
\hline Entomoneis sp. 1 & 15543 & 40 & 0 \\
\hline Entomoneis sp. 2 & 5829 & 0 & 0 \\
\hline Fossula arctica & 34971 & 0 & 0 \\
\hline Fragilariopsis spp. & 501257 & 960 & 2309068 \\
\hline Gyrosigma sp. 1 & 2914 & 0 & 519540 \\
\hline Gyrosigma sp. 3 & 8743 & 0 & 0 \\
\hline Navicula directa & 7771 & 0 & 0 \\
\hline Navicula kariana var. detersa & 4857 & 0 & 115453 \\
\hline Navicula septentrionalis & 153486 & 0 & 0 \\
\hline Navicula vanhoeffenii & 15543 & 0 & 0 \\
\hline Nitzschia pellucida & 64114 & 0 & 230907 \\
\hline Nitzschia frigida & 344857 & 0 & 0 \\
\hline Nitzschia seriata & 45657 & 0 & 0 \\
\hline Nitzschia sp. 1 & 20400 & 0 & 0 \\
\hline Paralia sulcata & 0 & 0 & 288633 \\
\hline Pauliella taeniata & 129200 & 320 & 461814 \\
\hline Pinnularia quadratarea var. constricta & 3886 & 0 & 0 \\
\hline Pinnularia sp. 4 & 13600 & 0 & 0 \\
\hline Pleurosigma tenuiforme & 0 & 20 & 288633 \\
\hline Pseudogomphonema septentrionale & 10686 & 0 & 0 \\
\hline Thalassiosira spp. & 2914 & 60 & 0 \\
\hline Unidentified pennate diatoms & 450743 & 160 & 1096807 \\
\hline Unidentified centric diatoms & 7771 & 180 & 57727 \\
\hline Empty pennate diatoms & 12629 & 0 & 4127459 \\
\hline Empty centric diatoms & 0 & 0 & 981354 \\
\hline Unidentified flagellates & 3886 & 0 & 0 \\
\hline Total cells & 1969086 & 1880 & 12440103 \\
\hline Total cells (excluding empty) & 1956457 & 1880 & 7331290 \\
\hline
\end{tabular}


Table A-5. Station SEC2 $\left(170.958^{\circ} \mathrm{W}, 62.594^{\circ} \mathrm{N}\right)$. Sampled March 19, 2009 during the ice growth period.

\begin{tabular}{|c|c|c|c|}
\hline Species & $\begin{array}{l}\text { Ice algal } \\
\text { abundance } \\
\left(\text { cells } 1^{-1}\right)\end{array}$ & $\begin{array}{l}\text { Phytoplankton } \\
\text { abundance } \\
\left(\text { cells } 1^{-1}\right)\end{array}$ & $\begin{array}{c}\text { Flux rate } \\
\text { (cells m }^{-2} \\
\text { day }^{-1} \text { ) }\end{array}$ \\
\hline Ceratoneis closterium & 260204 & 80 & 794360 \\
\hline Chaetoceros spp. & 0 & 440 & 3610725 \\
\hline Cocconeis sp. 1 & 0 & 60 & 144429 \\
\hline Coscinodiscus spp. & 0 & 0 & 144429 \\
\hline Entomoneis sp. 1 & 86735 & 0 & 144429 \\
\hline Entomoneis sp. 2 & 86735 & 0 & 0 \\
\hline Fossula arctica & 0 & 40 & 794360 \\
\hline Fragilariopsis spp. & 398980 & 1020 & 1516505 \\
\hline Gyrosigma sp. 1 & 17347 & 0 & 0 \\
\hline Gyrosigma sp. 3 & 17347 & 0 & 0 \\
\hline Haslea sp. 1 & 52041 & 0 & 0 \\
\hline Navicula algida & 34694 & 0 & 0 \\
\hline Navicula directa & 381633 & 0 & 72215 \\
\hline Navicula granii & 69388 & 0 & 0 \\
\hline Navicula kariana var. detersa & 329592 & 0 & 0 \\
\hline Navicula transitans var. derasa & 0 & 20 & 0 \\
\hline Navicula trigonocephala var. depressa & 17347 & 0 & 0 \\
\hline Navicula valida & 34694 & 0 & 144429 \\
\hline Nitzschia pellucida & 277551 & 0 & 144429 \\
\hline Nitzschia frigida & 2012245 & 0 & 1877577 \\
\hline Nitzschia sigmoidea & 156122 & 0 & 288858 \\
\hline Nitzschia sp. 1 & 260204 & 0 & 361073 \\
\hline Paralia sulcata & 0 & 0 & 1949792 \\
\hline Pinnularia quadratarea var. constricta & 17347 & 0 & 0 \\
\hline Pinnularia quadratarea var. densestriata & 34694 & 0 & 0 \\
\hline Pinnularia sp. 4 & 138776 & 0 & 0 \\
\hline Pleurosigma spp. & 52041 & 0 & 0 \\
\hline Pleurosigma tenuiforme & 0 & 40 & 361073 \\
\hline Pseudogomphonema groenlandicum & 69388 & 0 & 0 \\
\hline Pseudogomphonema septentrionale & 86735 & 0 & 216644 \\
\hline Thalassiosira spp. & 0 & 20 & 1877577 \\
\hline Unidentified pennate diatoms & 2497959 & 140 & 3249653 \\
\hline Empty pennate diatoms & 0 & 420 & 3249653 \\
\hline Empty centric diatoms & 0 & 40 & 577716 \\
\hline
\end{tabular}


Table A-5, continued

Unidentified flagellates

Total cells

Total cells (excluding empty)

$\begin{array}{rrr}0 & 0 & 144429 \\ 7389796 & 2320 & 21664352 \\ 7389796 & 1860 & 17836983\end{array}$

Table A-6. Station MK1 (168.951 $\left.{ }^{\circ} \mathrm{W}, 62.728^{\circ} \mathrm{N}\right)$. Sampled 3/22/2009 during the ice growth period.

\begin{tabular}{|c|c|c|c|}
\hline Species & $\begin{array}{c}\text { Ice algal } \\
\text { abundance } \\
\left(\text { cells } 1^{-1}\right)\end{array}$ & $\begin{array}{l}\text { Phytoplankton } \\
\text { abundance } \\
\left(\text { cells } 1^{-1}\right)\end{array}$ & $\begin{array}{c}\text { Flux rate } \\
\left(\begin{array}{c}\text { cells m } \\
\left.\text { day }^{-1}\right)\end{array}\right.\end{array}$ \\
\hline Ceratoneis closterium & 35943 & 80 & 2315775 \\
\hline Chaetoceros spp. & 0 & 280 & 4824532 \\
\hline Cocconeis sp. 1 & 0 & 0 & 1543850 \\
\hline Cocconeis sp. 2 & 0 & 0 & 192981 \\
\hline Coscinodiscus spp. & 0 & 0 & 385963 \\
\hline Entomoneis sp. 1 & 34971 & 20 & 0 \\
\hline Entomoneis sp. 2 & 1943 & 0 & 0 \\
\hline Fossula arctica & 0 & 0 & 771925 \\
\hline Fragilariopsis spp. & 167086 & 1060 & 3859625 \\
\hline Gyrosigma sp. 1 & 971 & 0 & 385963 \\
\hline Gyrosigma sp. 3 & 30114 & 20 & 0 \\
\hline Navicula directa & 48571 & 80 & 0 \\
\hline Navicula kariana var. detersa & 43714 & 0 & 0 \\
\hline Navicula septentrionalis & 15543 & 0 & 0 \\
\hline Navicula valida & 11657 & 20 & 0 \\
\hline Navicula vanhoeffenii & 15543 & 0 & 0 \\
\hline Nitzschia pellucida & 198171 & 80 & 0 \\
\hline Nitzschia frigida & 369143 & 0 & 0 \\
\hline Nitzschia seriata & 12629 & 0 & 0 \\
\hline Nitzschia sp. 1 & 65086 & 20 & 0 \\
\hline Paralia sulcata & 0 & 380 & 2508757 \\
\hline Pinnularia quadratarea var. bicontracta & 10686 & 0 & 0 \\
\hline Pinnularia quadratarea var. constricta & 3886 & 0 & 0 \\
\hline Pinnularia quadratarea var. cuneata & 9714 & 0 & 0 \\
\hline
\end{tabular}


Table A-6, continued

$\begin{array}{lrrr}\text { Pinnularia quadratarea var. dubia } & 0 & 0 & 192981 \\ \text { Pinnularia sp. 3 } & 14571 & 0 & 0 \\ \text { Pinnularia sp. 4 } & 46629 & 20 & 0 \\ \text { Pleurosigma spp. } & 20400 & 20 & 0 \\ \text { Pleurosigma tenuiforme } & 0 & 20 & 385963 \\ \text { Pseudogomphonema groenlandicum } & 4857 & 0 & 192981 \\ \text { Pseudogomphonema septentrionale } & 15543 & 40 & 0 \\ \text { Stenoneis inconspicua } & 26229 & 0 & 0 \\ \text { Thalassionema nitzschioides } & 0 & 120 & 771925 \\ \text { Thalassiosira spp. } & 0 & 0 & 3666644 \\ \text { Unidentified pennate diatoms } & 919943 & 240 & 16403408 \\ \text { Unidentified centric diatoms } & 1943 & 180 & 20841977 \\ \text { Empty pennate diatoms } & 6800 & 1380 & 48920752 \\ \text { Unidentified flagellates } & 2914 & 0 & 192981 \\ \text { Dinoflagellates } & 0 & 0 & 192981 \\ \text { Total cells } & 2135200 & 4060 & 108551965 \\ \text { Total cells (excluding empty) } & 2128400 & 2680 & 59631213\end{array}$

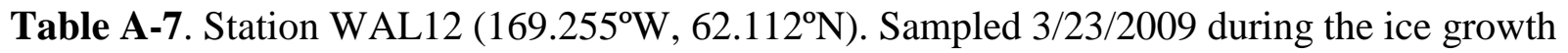
period.

\begin{tabular}{|c|c|c|c|}
\hline Species & $\begin{array}{l}\text { Ice algal } \\
\text { abundance } \\
\left(\text { cells } 1^{-1}\right)\end{array}$ & $\begin{array}{l}\text { Phytoplankton } \\
\text { abundance } \\
\left(\text { cells l}^{-1}\right)\end{array}$ & $\begin{array}{c}\text { Flux rate } \\
(\text { cells m } \\
\left.\text { day }^{-1}\right)\end{array}$ \\
\hline Ceratoneis closterium & 59925 & 840 & 393120 \\
\hline Chaetoceros spp. & 0 & 160 & 2162162 \\
\hline Cocconeis sp. 1 & 0 & 120 & 294840 \\
\hline Coscinodiscus spp. & 0 & 40 & 196560 \\
\hline Entomoneis sp. 1 & 1677903 & 1920 & 98280 \\
\hline Entomoneis sp. 2 & 119850 & 0 & 0 \\
\hline Fossula arctica & 29963 & 160 & 3783784 \\
\hline Fragilariopsis spp. & 4299625 & 7160 & 4471744 \\
\hline Gyrosigma sp. 1 & 59925 & 80 & 245700 \\
\hline Gyrosigma sp. 3 & 134831 & 160 & 0 \\
\hline
\end{tabular}


Table A-7, continued

\begin{tabular}{|c|c|c|c|}
\hline Haslea sp. 1 & 44944 & 0 & 0 \\
\hline Melosira arctica & 44944 & 0 & 0 \\
\hline Navicula algida & 29963 & 0 & 0 \\
\hline Navicula directa & 179775 & 280 & 245700 \\
\hline Navicula kariana var. detersa & 314607 & 200 & 245700 \\
\hline Navicula septentrionalis & 1318352 & 1000 & 0 \\
\hline Navicula transitans & 74906 & 40 & 393120 \\
\hline Navicula trigonocephala & 44944 & 0 & 0 \\
\hline Navicula trigonocephala var. depressa & 74906 & 40 & 0 \\
\hline Navicula valida & 0 & 240 & \\
\hline Navicula vanhoeffenii & 269663 & 0 & 0 \\
\hline Nitzschia pellucida & 599251 & 880 & 1425061 \\
\hline Nitzschia frigida & 958801 & 3120 & 982801 \\
\hline Nitzschia seriata & 434457 & 0 & 0 \\
\hline Nitzschia sigmoidea & 119850 & 240 & 0 \\
\hline Nitzschia sp. 1 & 179775 & 80 & 0 \\
\hline Nitzschia sp. 2 & 44944 & 0 & 147420 \\
\hline Paralia sulcata & 0 & 560 & 1031941 \\
\hline Pauliella taeniata & 0 & 0 & 245700 \\
\hline Pinnularia quadratarea var. bicontracta & 44944 & 0 & 0 \\
\hline Pinnularia quadratarea var. capitata & 14981 & 0 & $\Omega$ \\
\hline Pinnularia quadratarea var. constricta & 89888 & 80 & 0 \\
\hline Pinnularia quadratarea var. cuneata & 59925 & 0 & 0 \\
\hline Pinnularia quadratarea var. densestriata & 14981 & 0 & 49140 \\
\hline Pinnularia quadratarea var. dubia & 14981 & 0 & 0 \\
\hline Pinnularia quadratarea var. maxima & 0 & 80 & 0 \\
\hline Pinnularia sp. 1 & 134831 & 0 & U \\
\hline Pinnularia sp. 4 & 239700 & 160 & 0 \\
\hline Pleurosigma tenuiforme & 0 & 80 & 687961 \\
\hline Pseudogomphonema groenlandicum & 494382 & 120 & 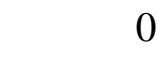 \\
\hline Pseudogomphonema septentrionale & 314607 & 40 & 0 \\
\hline Stenoneis inconspicua & 149813 & 0 & 0 \\
\hline Thalassionema nitzschioides & 0 & 80 & 196560 \\
\hline Thalassiosira spp. & 0 & 120 & 196560 \\
\hline Unidentified pennate diatoms & 7790262 & 6560 & 1179361 \\
\hline Unidentified centric diatoms & 0 & 360 & 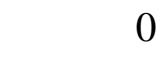 \\
\hline Empty pennate diatoms & 0 & 2120 & 3366093 \\
\hline Empty centric diatoms & 0 & 140 & 294840 \\
\hline Dinoflagellates & 0 & 0 & 49140 \\
\hline
\end{tabular}


Table A-7, continued

Total cells

20479401

27260

22383292

Total cells (excluding empty)

20479401

25000

18722359

Table A-8. Station MK1B (169.023W, 62.699N). Sampled March 25, 2009 during the ice growth period.

\begin{tabular}{|c|c|c|c|}
\hline Species & $\begin{array}{l}\text { Ice algal } \\
\text { abundance } \\
\left(\text { cells } 1^{-1}\right)\end{array}$ & $\begin{array}{l}\text { Phytoplankton } \\
\text { abundance } \\
\left({\left.\text { cells } 1^{-1}\right)}\right.\end{array}$ & $\begin{array}{c}\text { Flux rate } \\
\left(\text { cells m }^{-2}\right. \\
\left.\text { day }^{-1}\right)\end{array}$ \\
\hline Ceratoneis closterium & 14907 & 180 & 1038096 \\
\hline Chaetoceros spp. & 2080 & 120 & 655640 \\
\hline Cocconeis sp. 2 & 0 & 0 & 54637 \\
\hline Coscinodiscus spp. & 347 & 0 & 109273 \\
\hline Entomoneis sp. 1 & 2773 & 0 & 218547 \\
\hline Fossula arctica & 0 & 580 & 109273 \\
\hline Fragilariopsis spp. & 119253 & 1100 & 5299753 \\
\hline Gyrosigma sp. 1 & 0 & 0 & 109273 \\
\hline Gyrosigma sp. 3 & 0 & 20 & 163910 \\
\hline Navicula directa & 6240 & 0 & 218547 \\
\hline Navicula kariana var. detersa & 5200 & 60 & 163910 \\
\hline Navicula septentrionalis & 10400 & 0 & 0 \\
\hline Navicula superba & 6587 & 0 & 0 \\
\hline Nitzschia pellucida & 69333 & 100 & 764913 \\
\hline Nitzschia frigida & 89440 & 60 & 3988474 \\
\hline Nitzschia sigmoidea & 5893 & 0 & 0 \\
\hline Nitzschia sp. 1 & 23573 & 0 & 0 \\
\hline Nitzschia sp. 2 & 3120 & 0 & 0 \\
\hline Paralia sulcata & 1040 & 80 & 273183 \\
\hline Pauliella taeniata & 0 & 100 & 0 \\
\hline Pinnularia quadratarea var. bicontracta & 347 & 0 & 0 \\
\hline Pinnularia quadratarea var. constricta & 1040 & 0 & 0 \\
\hline Pinnularia quadratarea var. dubia & 1040 & 0 & 0 \\
\hline Pinnularia sp. 4 & 4160 & 20 & 218547 \\
\hline Pleurosigma spp. & 1387 & 0 & 0 \\
\hline Pleurosigma tenuiforme & 347 & 0 & 273183 \\
\hline
\end{tabular}


Table A-8, continued

$\begin{array}{lrrr}\text { Pseudogomphonema groenlandicum } & 1040 & 0 & 0 \\ \text { Pseudogomphonema septentrionale } & 14213 & 40 & 273183 \\ \text { Thalassiosira spp. } & 5547 & 40 & 109273 \\ \text { Unidentified pennate diatoms } & 172293 & 440 & 1529826 \\ \text { Unidentified centric diatoms } & 693 & 0 & 0 \\ \text { Empty pennate diatoms } & 29120 & 1890 & 4862660 \\ \text { Empty centric diatoms } & 0 & 60 & 355138 \\ \text { Unidentified flagellates } & 693 & 0 & 0 \\ \text { Dinoflagellates } & 693 & 0 & 0 \\ \text { Total cells } & 592800 & 4890 & 20789236 \\ \text { Total cells (excluding empty) } & 563680 & 2940 & 15571438\end{array}$

Table A-9. Station NWC3 $\left(173.387^{\circ} \mathrm{W}, 62.682^{\circ} \mathrm{N}\right)$. Sampled March 27, 2009 during the ice growth period.

\begin{tabular}{lrrr} 
Species & $\begin{array}{r}\text { Ice algal } \\
\text { abundance } \\
\left(\text { cells 1 }^{-1}\right)\end{array}$ & $\begin{array}{c}\text { Phytoplankton } \\
\text { abundance } \\
\left(\text { cells 1 }^{-1}\right)\end{array}$ & $\begin{array}{r}\text { Flux rate } \\
\left(\text { cells m }^{-2}\right. \\
\left.\text { day }^{-1}\right)\end{array}$ \\
\hline Ceratoneis closterium & & & \\
Chaetoceros spp. & 2702 & 260 & 726952 \\
Cocconeis sp. 3 & 676 & 300 & 1696222 \\
Coscinodiscus spp. & 0 & 20 & 0 \\
Entomoneis sp. 1 & 169 & 0 & 848111 \\
Fossula arctica & 0 & 20 & 0 \\
Fragilariopsis spp. & 0 & 640 & 0 \\
Gyrosigma sp. 1 & 0 & 3420 & 8602270 \\
Navicula directa & 169 & 40 & 0 \\
Navicula septentrionalis & 591 & 180 & 0 \\
Paralia sulcata & 0 & 0 & 3392445 \\
Pauliella taeniata & 0 & 180 & 1938540 \\
Pinnularia quadratarea var. constricta & 0 & 0 & 2302016 \\
Pleurosigma tenuiforme & 169 & 0 & 0 \\
Thalassiosira spp. & 0 & 20 & 121159 \\
Unidentified pennate diatoms & 2364 & 100 & 2907810 \\
& 9711 & 2500 & 9935016
\end{tabular}




\section{Table A-9, continued}

Unidentified centric diatoms

$\begin{array}{rrr}2027 & 340 & 4725191 \\ 0 & 520 & 17143961 \\ 0 & 60 & 0 \\ 56450 & 7680 & 32470540 \\ 44375 & 5080 & 19627715\end{array}$

Table A-10. Station MN4.5 (169.938 W, 59.937º N). Sampled April 7, 2009 during the ice growth period. No water samples available from this station.

\begin{tabular}{|c|c|c|c|}
\hline Species & $\begin{array}{c}\text { Ice algal } \\
\text { abundance } \\
\left(\text { cells } 1^{-1}\right)\end{array}$ & $\begin{array}{c}\text { Phytoplankton } \\
\text { abundance } \\
\left(\text { cells l }^{-1}\right)\end{array}$ & $\begin{array}{c}\text { Flux rate } \\
\left(\begin{array}{c}\text { cells m } \\
\text { day }\end{array}\right. \\
\left.\text { day }^{-1}\right)\end{array}$ \\
\hline Actinoptychus spp. & 0 & $\mathrm{n} / \mathrm{a}$ & 580737 \\
\hline Ceratoneis closterium & 122222 & & 0 \\
\hline Chaetoceros spp. & 244444 & & 3194054 \\
\hline Cocconeis sp. 1 & 0 & & 725921 \\
\hline Coscinodiscus spp. & 0 & & 1016290 \\
\hline Entomoneis sp. 1 & 4400000 & & 0 \\
\hline Entomoneis sp. 2 & 366667 & & 0 \\
\hline Fossula arctica & 122222 & & 0 \\
\hline Fragilariopsis spp. & 45038889 & & 13792508 \\
\hline Navicula directa & 61111 & & 0 \\
\hline Navicula kariana var. detersa & 122222 & & 0 \\
\hline Navicula septentrionalis & 1283333 & & 0 \\
\hline Navicula transitans & 61111 & & 145184 \\
\hline Navicula trigonocephala var. depressa & 61111 & & 0 \\
\hline Navicula valida & 183333 & & 0 \\
\hline Navicula vanhoeffenii & 611111 & & 0 \\
\hline Nitzschia pellucida & 2200000 & & 0 \\
\hline Nitzschia delicatissima & 611111 & & 0 \\
\hline Nitzschia frigida & 7088889 & & 0 \\
\hline Nitzschia seriata & 1222222 & & 0 \\
\hline Nitzschia sigmoidea & 0 & & 725921 \\
\hline Nitzschia sp. 1 & 61111 & & 0 \\
\hline Nitzschia sp. 2 & 366667 & & 290369 \\
\hline
\end{tabular}


Table A-10, continued

Odontella aurita

61111

435553

Paralia sulcata

0

Pleurosigma spp.

61111

Pseudogomphonema groenlandicum

122222

916667

Pseudogomphonema septentrionale

0

Thalassionema nitzschioides

10877778

Unidentified pennate diatoms

0

Empty pennate diatoms

Empty centric diatoms

0

76266667

14663614

290369

Dinoflagellates

76266667

Total cells (excluding empty)

725921

1451843

580737

1234067

290369

40143458

38328654

Table A-11. Station MN15 (176.416 $\left.{ }^{\circ} \mathrm{W}, 59.902^{\circ} \mathrm{N}\right)$. Sampled April 10, 2008 during the ice melt period.

\begin{tabular}{lrrr} 
Species & $\begin{array}{c}\text { Ice algal } \\
\text { abundance } \\
\left(\text { cells l }^{-1}\right)\end{array}$ & $\begin{array}{c}\text { Phytoplankton } \\
\text { abundance } \\
\left(\text { cells l }^{-1}\right)\end{array}$ & $\begin{array}{r}\text { Flux rate } \\
\left(\text { cells m }^{-2}\right. \\
\left.\text { day }^{-1}\right)\end{array}$ \\
\hline Entomoneis sp. 1 & & & \\
Fragilariopsis spp. & 0 & 200 & 187824 \\
Gyrosigma sp. 1 & 4344569 & 8500 & 187260715 \\
Navicula directa & 284644 & 200 & 610429 \\
Navicula kariana var. detersa & 14981 & 0 & 0 \\
Navicula septentrionalis & 209738 & 0 & 0 \\
Navicula valida & 14981 & 1200 & 2629539 \\
Nitzschia frigida & 14981 & 0 & 0 \\
Nitzschia seriata & 2112360 & 1600 & 3521704 \\
Pauliella taeniata & 0 & 0 & 375648 \\
Pinnularia quadratarea var. constricta & 14981 & 0 & 3568660 \\
Pinnularia quadratarea var. dubia & 0 & 100 & 0 \\
Pseudogomphonema groenlandicum & 89888 & 0 & 0 \\
Pseudogomphonema septentrionale & 119850 & 0 & 0 \\
Thalassionema nitzschioides & 434457 & 0 & 0 \\
& 0 & 0 & 281736
\end{tabular}


Table A-11, continued

Thalassiosira spp.

$\begin{array}{rrr}149813 & 0 & 1126945 \\ 3775281 & 7800 & 22163254 \\ 0 & 0 & 4695605 \\ 74906 & 0 & 0 \\ 14981 & 0 & 0 \\ 11670412 & 19600 & 226422058 \\ 11670412 & 19600 & 221726454\end{array}$

Table A-12. Station SL8.25 (172.830 $\left.\mathrm{W}, 62.074^{\circ} \mathrm{N}\right)$. Sampled April 12, 2008 during the ice melt period.

\begin{tabular}{|c|c|c|c|}
\hline Species & $\begin{array}{l}\text { Ice algal } \\
\text { abundance } \\
\left(\text { cells } 1^{-1}\right)\end{array}$ & $\begin{array}{l}\text { Phytoplankton } \\
\text { abundance } \\
\left(\text { cells } 1^{-1}\right)\end{array}$ & $\begin{array}{c}\text { Flux rate } \\
(\text { cells m } \\
\left.\text { day }^{-1}\right)\end{array}$ \\
\hline Ceratoneis closterium & 36620 & 0 & 325866 \\
\hline Coscinodiscus spp. & 0 & 0 & 65173 \\
\hline Entomoneis sp. 1 & 1757746 & 140 & 260693 \\
\hline Fossula arctica & 21898592 & 36820 & 4431777 \\
\hline Fragilariopsis spp. & 81112676 & 13780 & 72146726 \\
\hline Gyrosigma sp. 1 & 402817 & 40 & 65173 \\
\hline Navicula directa & 36620 & 60 & 0 \\
\hline Navicula septentrionalis & 1904225 & 0 & 2378822 \\
\hline Nitzschia frigida & 2490141 & 520 & 293279 \\
\hline Nitzschia seriata & 0 & 520 & 0 \\
\hline Nitzschia sp. 2 & 0 & 0 & 619145 \\
\hline Paralia sulcata & 0 & 0 & 391039 \\
\hline Pauliella taeniata & 1464789 & 3740 & 1042771 \\
\hline Pleurosigma tenuiforme & 0 & 0 & 195520 \\
\hline Pseudogomphonema septentrionale & 36620 & 0 & 0 \\
\hline Thalassiosira spp. & 0 & 1800 & 2215889 \\
\hline Unidentified pennate diatoms & 14940845 & 7760 & 11144616 \\
\hline Unidentified centric diatoms & 0 & 40 & 293279 \\
\hline Empty pennate diatoms & 0 & 170 & 1156824 \\
\hline Empty centric diatoms & 0 & 0 & 146640 \\
\hline
\end{tabular}


Table A-12, continued

Unidentified flagellates

Dinoflagellates

Total cells

Total cells (excluding empty)

$\begin{array}{rrr}0 & 0 & 97760 \\ 0 & 0 & 65173 \\ 126081690 & 65390 & 97336166 \\ 126081690 & 65220 & 96032702\end{array}$

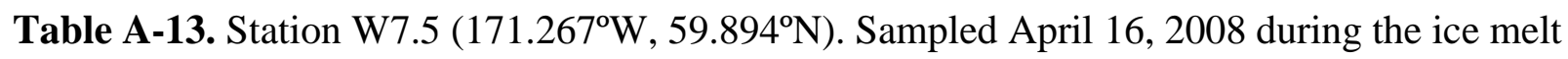
period.

\begin{tabular}{|c|c|c|c|}
\hline Species & $\begin{array}{l}\text { Ice algal } \\
\text { abundance } \\
\left(\text { cells } 1^{-1}\right)\end{array}$ & $\begin{array}{l}\text { Phytoplankton } \\
\text { abundance } \\
\left(\text { cells } 1^{-1}\right)\end{array}$ & $\begin{array}{l}\text { Flux rate } \\
\left(\text { cells m }^{-2}\right. \\
\left.\text { day }^{-1}\right)\end{array}$ \\
\hline Ceratoneis closterium & 328386 & 100 & 0 \\
\hline Entomoneis sp. 1 & 328386 & 0 & 0 \\
\hline Entomoneis sp. 2 & 32839 & 0 & 0 \\
\hline Fossula arctica & 0 & 540 & 0 \\
\hline Fragilariopsis spp. & 18126902 & 18400 & 4736609 \\
\hline Gyrosigma sp. 1 & 558256 & 60 & 87715 \\
\hline Navicula directa & 459740 & 40 & 263145 \\
\hline Navicula granii & 525417 & 0 & 0 \\
\hline Navicula kariana var. detersa & 1346382 & 0 & 175430 \\
\hline Navicula septentrionalis & 492579 & 0 & 0 \\
\hline Navicula valida & 164193 & 0 & 0 \\
\hline Nitzschia frigida & 2265863 & 60 & 0 \\
\hline Nitzschia seriata & 229870 & 0 & 0 \\
\hline Nitzschia sp. 2 & 0 & 140 & 0 \\
\hline Odontella aurita & 0 & 0 & 87715 \\
\hline Paralia sulcata & 0 & 0 & 3859459 \\
\hline Pinnularia quadratarea var. constricta & 361224 & 0 & 0 \\
\hline Pleurosigma tenuiforme & 65677 & 0 & 0 \\
\hline Pseudogomphonema septentrionale & 229870 & 40 & 0 \\
\hline Thalassionema nitzschioides & 0 & 140 & 350860 \\
\hline Thalassiosira spp. & 0 & 1200 & 526290 \\
\hline Unidentified pennate diatoms & 10606865 & 5400 & 614005 \\
\hline Unidentified centric diatoms & 5319852 & 0 & 0 \\
\hline Empty pennate diatoms & 0 & 90 & 1008722 \\
\hline
\end{tabular}


Table A-13, continued

Unidentified flagellates

$\begin{array}{rrr}65677 & 0 & 87715 \\ 41507978 & 26210 & 11797666 \\ 41507978 & 26120 & 10788943\end{array}$

Table A-14. Station ST110 (172.555 $\left.{ }^{\circ} \mathrm{W}, 62.260^{\circ} \mathrm{N}\right)$. Sampled April 28, 2008 during the ice melt period.

\begin{tabular}{|c|c|c|c|}
\hline Species & $\begin{array}{l}\text { Ice algal } \\
\text { abundance } \\
\left(\text { cells } 1^{-1}\right)\end{array}$ & $\begin{array}{c}\text { Phytoplankton } \\
\text { abundance } \\
\left(\text { cells } 1^{-1}\right)\end{array}$ & $\begin{array}{c}\text { Flux rate } \\
\left(\begin{array}{c}\text { cells m } \\
\text { day }\end{array}\right. \\
\left.\text { day }^{-1}\right)\end{array}$ \\
\hline Ceratoneis closterium & 32484 & 0 & 0 \\
\hline Fossula arctica & 0 & 0 & 262342752 \\
\hline Fragilariopsis spp. & 7406369 & 2320 & 37823096 \\
\hline Gyrosigma sp. 1 & 32484 & 0 & 659705 \\
\hline Navicula directa & 97452 & 80 & 219902 \\
\hline Navicula granii & 129936 & 0 & 0 \\
\hline Navicula kariana var. detersa & 32484 & 0 & 439803 \\
\hline Navicula pelagica & 259873 & 0 & 0 \\
\hline Nitzschia frigida & 11174522 & 0 & 9675676 \\
\hline Nitzschia seriata & 0 & 0 & 439803 \\
\hline Paralia sulcata & 0 & 720 & 659705 \\
\hline Pauliella taeniata & 5814650 & 0 & 1979115 \\
\hline Pseudogomphonema septentrionale & 32484 & 0 & 0 \\
\hline Thalassiosira spp. & 584713 & 120 & 1759214 \\
\hline Unidentified pennate diatoms & 5424841 & 1000 & 6597052 \\
\hline Unidentified centric diatoms & 0 & 0 & 659705 \\
\hline Empty pennate diatoms & 0 & 0 & 549754 \\
\hline Dinoflagellates & 0 & 40 & 0 \\
\hline Total cells & 31022293 & 4280 & 323255528 \\
\hline Total cells (excluding empty) & 31022293 & 4280 & 323255528 \\
\hline
\end{tabular}


Table A-15. Station $70 \mathrm{M} 53\left(173.630^{\circ} \mathrm{W}, 61.505^{\circ} \mathrm{N}\right)$. Sampled April 30, 2008 during the ice melt period.

$\begin{array}{lrrr}\text { Species } & \begin{array}{r}\text { Ice algal } \\ \text { abundance } \\ \left(\text { cells l }^{-1}\right)\end{array} & \begin{array}{c}\text { Phytoplankton } \\ \text { abundance } \\ \left(\text { cells 1 }^{-1}\right)\end{array} & \begin{array}{r}\text { Flux rate } \\ \left(\text { cells }^{-2}\right. \\ \left.\text { day }^{-1}\right)\end{array} \\ \text { Ceratoneis closterium } & 594824 & & \\ \text { Chaetoceros spp. } & 0 & 0 & 529238 \\ \text { Entomoneis sp. } 1 & 0 & 80 & 0 \\ \text { Fossula arctica } & 0 & 1360 & 0 \\ \text { Fragilariopsis spp. } & 62946 & 1840 & 8644226 \\ \text { Gyrosigma } \text { sp. 1 } & 5948240 & 160 & 2028747 \\ \text { Navicula directa } & 314907 & 160 & 529238 \\ \text { Navicula granii } & 174948 & 0 & 0 \\ \text { Navicula kariana } \text { var. detersa } & 0 & 40 & 0 \\ \text { Nitzschia frigida } & 10532 & 120 & 0 \\ \text { Nitzschia seriata } & 0 & 0 & 352826 \\ \text { Paralia sulcata } & 0 & 0 & 3263636 \\ \text { Pauliella taeniata } & 40413 & 0 & 1058477 \\ \text { Pleurosigma tenuiforme } & 0 & 0 & 352826 \\ \text { Thalassionema nitzschioides } & 0 & 0 & 441032 \\ \text { Thalassiosira } \text { spp. } & 79601 & 880 & 2910811 \\ \text { Unidentified pennate diatoms } & 7522774 & 2360 & 3704668 \\ \text { Unidentified centric diatoms } & 0 & 120 & 0 \\ \text { Empty pennate diatoms } & 0 & 240 & 1896437 \\ \text { Unidentified flagellates } & 34990 & 80 & 0 \\ \text { Dinoflagellates } & 34990 & 0 & 0 \\ \text { Total cells } & 14819166 & 7480 & 25712162 \\ \text { Total cells (excluding empty) } & 14819166 & 7240 & 23815725\end{array}$


Table A-16. Station ST28 (176.986 W, 61.696 ${ }^{\circ}$ N). Sampled April 14, 2009 during the ice melt period. No water samples available from this station.

\begin{tabular}{|c|c|c|c|}
\hline Species & $\begin{array}{l}\text { Ice algal } \\
\text { abundance } \\
\left(\text { cells } 1^{-1}\right)\end{array}$ & $\begin{array}{c}\text { Phytoplankton } \\
\text { abundance } \\
\left(\text { ceells l-1 }^{-1}\right)\end{array}$ & $\begin{array}{c}\text { Flux rate } \\
(\text { cells m } \\
\left.\text { day }^{-1}\right)\end{array}$ \\
\hline Ceratoneis closterium & 90293 & $\mathrm{n} / \mathrm{a}$ & 0 \\
\hline Entomoneis sp. 1 & 1986436 & & 520906 \\
\hline Fragilariopsis spp. & 57245479 & & 10287888 \\
\hline Gyrosigma sp. 1 & 1986436 & & 130226 \\
\hline Haslea sp. 1 & 90293 & & 0 \\
\hline Navicula algida & 90293 & & 0 \\
\hline Navicula directa & 1805851 & & 0 \\
\hline Navicula kariana var. detersa & 632048 & & 0 \\
\hline Navicula septentrionalis & 29615957 & & 1041811 \\
\hline Navicula vanhoeffenii & 722340 & & 0 \\
\hline Nitzschia frigida & 18690559 & & 5469510 \\
\hline Nitzschia seriata & 1354388 & & 1041811 \\
\hline Nitzschia sigmoidea & 2889362 & & 260453 \\
\hline Nitzschia sp. 1 & 1354388 & & 0 \\
\hline Nitzschia sp. 2 & 722340 & & 390679 \\
\hline Pauliella taeniata & 2076729 & & 0 \\
\hline Pinnularia quadratarea var. constricta & 361170 & & 260453 \\
\hline Pseudogomphonema groenlandicum & 722340 & & 0 \\
\hline Pseudogomphonema septentrionale & 902926 & & 0 \\
\hline Unidentified pennate diatoms & 15078856 & & 1823170 \\
\hline Unidentified centric diatoms & 270878 & & 260453 \\
\hline Empty pennate diatoms & 0 & & 586019 \\
\hline Empty centric diatoms & 0 & & 130226 \\
\hline Silicoflagellate & 130226 & & 0 \\
\hline Total cells & 138819588 & & 22203606 \\
\hline Total cells (excluding empty) & 138819588 & & 21487361 \\
\hline
\end{tabular}


Table A-17. Station SL1 (167.754 $\left.{ }^{\circ} \mathrm{W}, 61.701^{\circ} \mathrm{N}\right)$. Sampled April 18, 2009 during the ice melt period. No water samples available from this station.

\begin{tabular}{|c|c|c|c|}
\hline Species & $\begin{array}{c}\text { Ice algal } \\
\text { abundance } \\
\left(\text { cells } 1^{-1}\right)\end{array}$ & 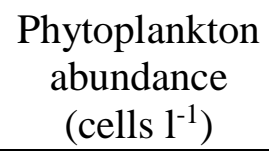 & $\begin{array}{c}\text { Flux rate } \\
(\text { cells m } \\
\left.\text { day }^{-1}\right)\end{array}$ \\
\hline Ceratoneis closterium & 114299 & $\mathrm{n} / \mathrm{a}$ & 301763 \\
\hline Chaetoceros spp. & 45720 & & 603527 \\
\hline Entomoneis sp. 1 & 365758 & & 1810580 \\
\hline Fragilariopsis spp. & 2468866 & & 62464998 \\
\hline Haslea sp. 1 & 45720 & & 0 \\
\hline Navicula algida & 22860 & & 0 \\
\hline Navicula septentrionalis & 160019 & & 0 \\
\hline Navicula trigonocephala var. depressa & 22860 & & 0 \\
\hline Navicula vanhoeffenii & 137159 & & 1207053 \\
\hline Nitzschia pellucida & 137159 & & 301763 \\
\hline Nitzschia frigida & 5212050 & & 3621159 \\
\hline Nitzschia seriata & 160019 & & 0 \\
\hline Nitzschia sigmoidea & 45720 & & 301763 \\
\hline Nitzschia sp. 1 & 297178 & & 301763 \\
\hline Paralia sulcata & 0 & & 2414106 \\
\hline Pinnularia quadratarea var. bicontracta & 22860 & & 0 \\
\hline Pinnularia quadratarea var. constricta & 45720 & & 0 \\
\hline Pinnularia quadratarea var. maxima & 22860 & & 0 \\
\hline Pinnularia sp. 4 & 251459 & & 0 \\
\hline Pleurosigma spp. & 274318 & & 1810580 \\
\hline Pseudogomphonema groenlandicum & 45720 & & 0 \\
\hline Pseudogomphonema septentrionale & 160019 & & 301763 \\
\hline Thalassiosira spp. & 0 & & 603527 \\
\hline Unidentified pennate diatoms & 2628885 & & 6940555 \\
\hline Unidentified centric diatoms & 0 & & 1207053 \\
\hline Empty pennate diatoms & 0 & & 1508816 \\
\hline Unidentified flagellates & 22860 & & 0 \\
\hline Silicoflagellate & 0 & & 301763 \\
\hline Total cells & 12710087 & & 86002534 \\
\hline Total cells (excluding empty) & 12710087 & & 84493718 \\
\hline
\end{tabular}


Table A-18. Station NP1 (167.798 $\left.\mathrm{W}, 59.448^{\circ} \mathrm{N}\right)$. Sampled April 20, 2009 during the ice growth period. No water samples available from this station.

\begin{tabular}{|c|c|c|c|}
\hline Species & $\begin{array}{c}\text { Ice algal } \\
\text { abundance } \\
\left(\text { cells } 1^{-1}\right)\end{array}$ & $\begin{array}{c}\text { Phytoplankton } \\
\text { abundance } \\
(\text { cells l-1) }\end{array}$ & $\begin{array}{c}\text { Flux rate } \\
\left(\text { cells m }^{-2}\right. \\
\left.\text { day }^{-1}\right)\end{array}$ \\
\hline Actinoptychus spp. & 0 & $\mathrm{n} / \mathrm{a}$ & 279974 \\
\hline Biddulphia spp. & 0 & & 279974 \\
\hline Ceratoneis closterium & 59479 & & 0 \\
\hline Cocconeis sp. 1 & 0 & & 466623 \\
\hline Cocconeis sp. 2 & 0 & & 279974 \\
\hline Coscinodiscus spp. & 0 & & 746596 \\
\hline Entomoneis sp. 1 & 1685236 & & 93325 \\
\hline Entomoneis sp. 2 & 99132 & & 93325 \\
\hline Fossula arctica & 257742 & & 1399868 \\
\hline Fragilariopsis spp. & 14631813 & & 9985727 \\
\hline Navicula directa & 158610 & & 0 \\
\hline Navicula kariana var. detersa & 297395 & & 0 \\
\hline Navicula transitans & 118958 & & 0 \\
\hline Navicula valida & 79305 & & 0 \\
\hline Navicula vanhoeffenii & 79305 & & 0 \\
\hline Nitzschia pellucida & 674094 & & 279974 \\
\hline Nitzschia frigida & 3370472 & & 0 \\
\hline Nitzschia sigmoidea & 39653 & & 93325 \\
\hline Nitzschia sp. 2 & 337047 & & 0 \\
\hline Paralia sulcata & 674094 & & 10452350 \\
\hline Pinnularia quadratarea var. constricta & 19826 & & 0 \\
\hline Pinnularia sp. 4 & 59479 & & 0 \\
\hline Pleurosigma spp. & 19826 & & 746596 \\
\hline Pleurosigma teuniforme & 0 & & 186649 \\
\hline Pseudogomphonema groenlandicum & 39653 & & 0 \\
\hline Pseudogomphonema septentrionale & 515484 & & 0 \\
\hline Thalassionema nitzschioides & 0 & & 186649 \\
\hline Thalassiosira spp. & 0 & & 746596 \\
\hline Unidentified pennate diatoms & 3390298 & & 4012956 \\
\hline Unidentified centric diatoms & 0 & & 653272 \\
\hline Empty pennate diatoms & 89218 & & 233311 \\
\hline Empty centric diatoms & 0 & & 839921 \\
\hline
\end{tabular}


Table A-18, continued

Silicoflagellate

0

93325

Total cells

26696120

32150307

Total cells (excluding empty)

26606901

31077075

Table A-19. Station ST92 $\left(173.692^{\circ} \mathrm{W}, 61.551^{\circ} \mathrm{N}\right)$. Sampled May 1, 2009 during the ice growth period. No water samples available from this station.

\begin{tabular}{|c|c|c|c|}
\hline Species & $\begin{array}{l}\text { Ice algal } \\
\text { abundance } \\
\left(\text { cells } 1^{-1}\right)\end{array}$ & $\begin{array}{l}\text { Phytoplankton } \\
\text { abundance } \\
\left(\text { cells } 1^{-1}\right)\end{array}$ & $\begin{array}{c}\text { Flux rate } \\
\left(\text { cells m }^{-2}\right. \\
\left.\text { day }^{-1}\right)\end{array}$ \\
\hline Ceratoneis closterium & 125467 & $\mathrm{n} / \mathrm{a}$ & 0 \\
\hline Chaetoceros spp. & 0 & & 474093 \\
\hline Entomoneis sp. 1 & 1317405 & & 632123 \\
\hline Entomoneis sp. 2 & 62734 & & 0 \\
\hline Fossula arctica & 1129204 & & 4345849 \\
\hline Fragilariopsis spp. & 6210623 & & 7269420 \\
\hline Gyrosigma sp. 1 & 313668 & & 0 \\
\hline Gyrosigma sp. 3 & 0 & & 237046 \\
\hline Haslea sp. 1 & 62734 & & 0 \\
\hline Navicula directa & 376401 & & 79015 \\
\hline Navicula kariana var. detersa & 188201 & & 0 \\
\hline Navicula septentrionalis & 2446609 & & 0 \\
\hline Navicula vanhoeffenii & 250934 & & 158031 \\
\hline Nitzschia pellucida & 752803 & & 316062 \\
\hline Nitzschia frigida & 43348893 & & 0 \\
\hline Nitzschia sigmoidea & 878270 & & 0 \\
\hline Nitzschia sp. 1 & 250934 & & 0 \\
\hline Nitzschia sp. 2 & 125467 & & 395077 \\
\hline Pinnularia quadratarea var. constricta & 62734 & & 0 \\
\hline Pinnularia sp. 4 & 125467 & & 0 \\
\hline Pseudogomphonema septentrionale & 815536 & & 0 \\
\hline Thalassiosira spp. & 0 & & 1422278 \\
\hline Unidentified pennate diatoms & 5520554 & & 711139 \\
\hline Unidentified centric diatoms & 0 & & 79015 \\
\hline
\end{tabular}


Table A-19, continued

Empty pennate diatoms

62734

158031

Empty centric diatoms

0

513600

Total cells

64427370

16790779

Total cells (excluding empty)

64364637

16119148

Table A-20. Station BN1 (172.517º, $\left.62.251^{\circ} \mathrm{N}\right)$. Sampled May 2, 2009 during the ice growth period. No water samples available from this station.

\begin{tabular}{|c|c|c|c|}
\hline Species & $\begin{array}{l}\text { Ice algal } \\
\text { abundance } \\
\left(\text { cells l }^{-1}\right)\end{array}$ & $\begin{array}{l}\text { Phytoplankton } \\
\text { abundance } \\
\left(\text { cells } 1^{-1}\right)\end{array}$ & $\begin{array}{l}\text { Flux rate } \\
(\text { cells m } \\
\left.\text { day }^{-1}\right)\end{array}$ \\
\hline Entomoneis sp. 1 & 232222 & $\mathrm{n} / \mathrm{a}$ & 0 \\
\hline Fossula arctica & 24035000 & & 121149017 \\
\hline Fragilariopsis spp. & 17823056 & & 185499991 \\
\hline Navicula granii & 348333 & & 0 \\
\hline Navicula septentrionalis & 9056667 & & 0 \\
\hline Nitzschia frigida & 4238056 & & 0 \\
\hline Nitzschia sigmoidea & 58056 & & 0 \\
\hline Nitzschia sp. 1 & 58056 & & 0 \\
\hline Nitzschia sp. 2 & 116111 & & 0 \\
\hline Pauliella taeniata & 41858056 & & 25377849 \\
\hline Pleurosigma tenuiforme & 0 & & 604234 \\
\hline Thalassionema nitzschioides & 116111 & & 0 \\
\hline Thalassiosira spp. & 464444 & & 8761400 \\
\hline Unidentified pennate diatoms & 9230833 & & 12991042 \\
\hline Empty pennate diatoms & 87083 & & 0 \\
\hline Unidentified flagellates & 58056 & & 0 \\
\hline Dinoflagellates & 9230833 & & 12991042 \\
\hline Silicoflagellate & 87083 & & 0 \\
\hline Total cells & 117098056 & & 367374574 \\
\hline Total cells without empty & 117010972 & & 367374574 \\
\hline
\end{tabular}

